\title{
THE QUEST FOR INFORMATION RETRIEVAL: AN INSCRIBED RELIC FROM ANCIENT RAPA NUI (EASTER ISLAND) - Part II.
}

\author{
Tomi S. MELKA \\ (Las Palmas de G.C., Spain) \\ tmelka@gmail.com \\ Robert M. SCHOCH \\ (Boston, Massachusetts, USA) \\ schoch@bu.edu
}

\begin{abstract}
In Part I of this article (Melka and Schoch 2021), ${ }^{1}$ we described an antique wooden artifact from Easter Island, known as the "Lutz-Terasaki fragment", that bears a single rongorongo glyph. Here we focus further on the "Lutz-Terasaki fragment", gleaning as much evidence as we can by resorting to a complex analysis. The ethno-linguistic, epigraphic, and xylological data point - thus far - toward the remains of an artifact of utilitarian and/or ritualistic scope.

In order to exhaust every potentiality regarding the "Lutz-Terasaki fragment" and the meaning of the glyph that it bears, we must consider similar contexts that may appear in the future if other artifacts are located bearing the same or a similar glyph. It is acknowledged that in the absence of new corroborating evidence, even the best-formed hypotheses concerning rongorongo glyphs and sequences may stretch too thin and, quite often, be summarily dismissed or simply ignored.

Continuing investigation and rational conversation with scholars of Rapa Nui, we have found to our profit, are efficacious ways to respond to hypothetical settings. To suggest otherwise would be highly arguable or erroneous.
\end{abstract}

Keywords: decipherment; hapax graphomenon; mata'a / matā; pre-missionary era; Rapa Nui (Easter Island); rongorongo glyph(s) of the /600/-series; the "Lutz-Terasaki fragment" artifact; toki; wooden handle

${ }^{1}$ MELKA, T. S., SCHOCH, R. M. The Quest for Information Retrieval: An Inscribed Relic from Ancient Rapa Nui (Easter Island), Part I. 
"On one point we can at least be certain, the archaeological pursuit of [the meaning of] signs is no easy business".

Christopher Tilley ${ }^{2}$

\section{Possible Meaning and Context of the Incised "Lutz-Terasaki” Glyph}

An important question that should be raised now is whether one should attempt to decipher or interpret the glyph at issue. The term decipherment per Maurice Pope $^{3}$ "means the explanation (by transliteration ${ }^{4}$ or otherwise) of the individual signs of a script. It does not mean understanding the sense of particular texts written in it". Note, too, that Michael Coe ${ }^{5}$ agrees to Pope's "generally accepted use of the term $[. .$.$] " and renders it as " [\ldots]$ the matching of each sign [= a rongorongo glyph, thereof in the case being herein discussed] to a definite sound or word in the ancient language [= pre-missionary Rapanui in the case of rongorongo]". Conversely, interpretation stands for incorporating the meaning of the "Lutz-Terasaki" glyph (Fig. 1) into our understanding via (a) a structural (= relational) analysis; (b) an iconographic study - based on representational and/or symbolic meaning; and (c) the comparison of the social connotations and associations of different pre-missionary Rapanui artifacts, representations, and styles (see Section PLATES). Other contexts, circumstances, and methods are similarly conducive to our aim, with the interpretation itself being subject to further revalidations (or possible falsification). ${ }^{7}$

${ }^{2}$ TILLEY, C. Interpreting Material Culture, p. 72.

${ }^{3}$ POPE, M. The Story of Decipherment: From Egyptian Hieroglyphs to Maya Script, Glossary of Technical Terms, p. 215; cf. COE, M. Phallus and Fallacy. Glyph-Breaker - Rongorongo.

${ }^{4}$ Otherwise, POPE, M. The Story of Decipherment: From Egyptian Hieroglyphs to Maya Script, Glossary of Technical Terms, p. 217, elucidates the term "transliteration" as the "re-writing a text from another script by means of the signary of one's own (if necessary artificially augmented) in such a way that there is a one-to-one correspondence between the signs or sign-groups used".

${ }^{5}$ COE, M. Phallus and Fallacy. Glyph-Breaker - Rongorongo.

${ }^{6}$ For the initial description of the "Lutz-Terasaki fragment", see MELKA, T. S., SCHOCH, R. M. The Quest for Information Retrieval: An Inscribed Relic from Ancient Rapa Nui (Easter Island), Part I.

${ }^{7}$ See especially ROBB, J. E. The Archaeology of Symbols, p. 341. 
The Quest for Information Retrieval - Part II

We acknowledge that Easter Island has churned out "mysteries" for more than a century and a half, and the greatest of all of them seems to be its premissionary classical script. ${ }^{8}$ Given the customary uncertainties and all too typically conflicting views over particular rongorongo $(=\mathrm{RR})$ glyphs or the script in general during the post-1864 period (1864 marking the year of the arrival of the missionary Joseph-Eugène Eyraud [1820 - 1868] on the island), ${ }^{9}$ phonetic decipherments have produced results that wind up in multiple, random directions. Suffice to say that under the phonetic circumstances, scholarly discord is the standard measure in the rongorongo studies. Attractive and plausible hypotheses, on the other side, bearing the mark of a careful interpretation have paved the way for a growing consensus as to the meaning of certain individual glyphs, parallel sequences, or text categories. Decanting for the latter approach would be the wisest thereof. In like manner, when it comes to interpreting and/or deciphering the rongorongo signs, we believe the strict tenet "let professionals [= epigraphers, linguists] do their job" should be viewed with reservation. ${ }^{10}$ The so-called amateurs (whether in a "go-it-alone" mode or cooperating at the present time or in the years to come) may prove invaluable in the elucidation of various scribal aspects and support materials too, so long as they base their estimates on hard facts ${ }^{11}$ and review objectively and thoroughly the RR-related literature.

\footnotetext{
${ }^{8}$ See LEHMANN, W. Essai d'une Monographie Bibliographique sur l' ̂lle de Pâques, p. 141, "Beaucoup de questions restent encore ici sans solution, notamment l'intéressant et difficile problème des hiéroglyphes" [Many questions remain here without a solution, notably the interesting and difficult problem of the hieroglyphic signs]; cf. ninety (90) years later, FISCHER, S. R. Rongorongo: The Easter Island Script, History, Traditions, Texts, p. vii, “[...] the Britons Paul Bahn and John Flenley (1992: 203) have only recently identified rongorongo to be 'the one genuine mystery that remains from the island's past"'.

${ }^{9}$ FISCHER, S. R. Rongorongo: The Easter Island Script, History, Traditions, Texts, p. 11.

${ }^{10}$ Consider that the status of "professional" in the area of rongorongo studies could be set in vaguely - or in strongly defined terms according to personal / selfish criteria. The issue can be a flashpoint in this debate since an " $\mathrm{A}$ ", "B", or " $\mathrm{C}$ " published author may be a "professional" (and apparently getting to set the rules) according to one perspective; yet, according to other ones, "A", "B", or " $\mathrm{C}$ " may have a self-serving argumentative structure or may be inclined to self-promotion. The "mystery" of rongorongo seems to leave a window open for a diverse cast of researchers to sneak in, and clearly, they might not (or are unwilling to) get along scholarly with each other.

${ }^{11}$ This is a matter for concern since (over the years) various people have attempted to explain the extant rongorongo data based on "alternative" or "personal" facts.
} 
In terms of iconography, the "Lutz-Terasaki" glyph seems to represent an avian life-form, possibly integrating a "human"-like body feature (Fig. 1). As revealed in Georgia Lee's article, bird symbolism was widespread in Polynesia, ${ }^{12}$ finding its way into cultic events and other visual manifestations. The author states unequivocally further on, "Seabirds in particular influenced the imagination of Polynesians". ${ }^{13}$ The ancient Rapanui inhabitants were not free from such a cultural inclination. The "air of mystery", the appeal, and gracefulness that portrayed most of the avifauna was thus transferred into the cult of the Birdman, petroglyphs, rock art, stone figurines, wooden carvings, the design of rongorongo glyphs, etc. Examples are echoed, e.g., in Walter Lehmann's caption 'Statuette de bois en forme d'homme, mêlée de celle de pingouin. St. Pétersbourg. (Acad. Imp. des Sciences.) [Wooden statuette in a human-like form, a composite with that of a penguin (sic). Saint Petersburg. (Imperial Academy of Sciences.)]"; ${ }^{14}$ in Louis-Charles Watelin who comments, "Nous retrouvons l'homme-oiseau dans un signe tout à fait semblable aux sculptures d'Orongo (Île de Pâques) gardant alors son profil d'oiseau [...]" [We find the bird-man in a sign (= glyph) altogether similar to the sculptures of 'Orongo (Easter Island) while keeping his bird profile (...)], ${ }^{15}$ in Alfred Métraux, "Birds treated in exactly the same style as those on the [rongorongo; our note] tablets are carved on rocks, especially in caves and at Orongo where ceremonies dedicated to Makemake were held", 16 in one of the early articles of Thomas S. Barthel, "Con particular expectación se indagarán las inscripciones buscando datos que hagan referencia a problemas especiales de la isla de Pascua, tales como el culto ornitológico de Orongo, las grandes estatuas de piedra y las figuras talladas en madera. Desgraciadamente, los resultados han de ser muy escasos. De todas maneras, claramente se manifiesta la valoración de la golondrina de mar como pájaro sobrenatural, y en la mención de tangata manu hay reminiscencias a los juegos atléticos de Orongo [The (rongorongo) inscriptions will be examined with particular expectation, looking for referential data to special topics of Easter Island, such as the bird cult of 'Orongo, the great stone statues and the wooden carved figurines. Unfortunately, the results will have to be meager. In any event, it is clearly shown the distinction of the sea swallow as a supernatural bird, and in the mention of the birdman there are

\footnotetext{
${ }^{12}$ LEE, G. The Rock Art of Rapanui, p. 114.

${ }^{13}$ Ibid., p. 114.

${ }^{14}$ LEHMANN, W. Essai d'une Monographie Bibliographique sur l'Île de Pâques, Fig. 4.

${ }^{15}$ WATELIN, L.-C. Note sur l'Ecriture de l'Ile de Pâques, p. 64

${ }^{16}$ MÉTRAUX, A. Ethnology of Easter Island, p. 404.
} 
reminiscences of the athletic games of 'Orongo]; ${ }^{17}$ in Thor Heyerdahl's statement, "Birds of various kinds are the most commonly represented animals in Easter Island art, which is otherwise dominated by human figurines"; $; 8$ in Eric Kjellgren, who depicts a number of wooden "birdman" effigies; ${ }^{19}$ or in particular signs of the classical script, e.g., a "birdman" /610/ right (Da3); another "birdman" $/ 607 \mathrm{y} /$ ฟิํㅠ facing (this time) right-to-left (Da7); a "birdman" /610/ holding a "fish"-shaped glyph /700f/ with "thread"视俳

like filaments ? like glyph /291a/ with a "hollow belly" 胥包 (B $r 7)$. Significant are also many glyphs of series $/ 400 /$ shaped after manu tara [sooty tern (Sterna fuscata) $]^{20}$ and of series /600/ designed after makohe [the Great frigate bird (Fregata minor)]; ${ }^{21}$ see Fig. 2 (Section PLATES). As many instances of glyph /670/ $\sqrt{3}$ (plus

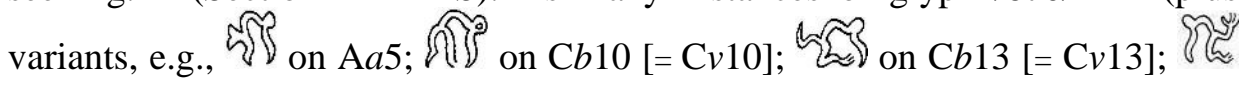

17 BARTHEL, T. S. Resultados Preliminares del Desciframiento de las Kohaurongorongo de la Isla de Pascua [Preliminary Results of the Decipherment of Easter Island's Kohau-rongorongo], p. 237.

${ }^{18}$ HEYERDAHL, T. The Art of Easter Island, p. 222.

${ }^{19}$ KJELLGREN, E. Splendid Isolation: Art of Easter Island, p. 36, Figure 16; pp. 46 47, Figures 4, 5, and 6.

${ }^{20}$ In BARTHEL, T. S. Rongorongo-Studien (Forschungen und Fortschritte bei der Weiteren Entzifferung der Osterinselschrift), manu tara is given in German as "Seeschwalbe" [sea swallow]; ZIZKA, G. Naturgeschichte der Osterinsel, p. 27, in the section "Fauna" identifies "Rußseeschwalbe" [sooty sea swallow] with Sterna fuscata and "Brillenseeschwalbe" [bespectacled sea swallow] with Sterna lunata. In JARAMILLO, A., JOHNSON, M. T. J., ROTHFELS, C. J., JOHNSON, R. A. The Native and Exotic Avifauna of Easter Island: Then and Now, p. 14, Table 1, Sooty Tern is listed after the Latin designation Onychoprion fuscatus luctuosus, with the Greybacked Tern as Onychoprion lunatus; whereas on page 17, the team JARAMILLO, A., et al. defines Sooty Tern under Sterna fuscata and the Grey-backed Tern under Sterna lunata. This ornithological discussion provides an opportunity to quote also BALFOUR, H. Some Ethnological Suggestions in regard to Easter Island, or Rapanui, p. 372, "[...] Manu tara, which dominated the [Birdman; our note] cult was a tern (the Sooty tern, sterna fuliginosa, known to sailors as the 'Wide-awake,' or 'Egg-bird')".

21 cf. BARTHEL, T. S. Rongorongo-Studien (Forschungen und Fortschritte bei der Weiteren Entzifferung der Osterinselschrift), p. 378. 


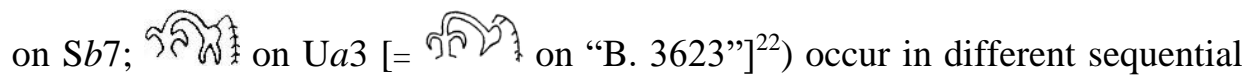
contexts and in (apparently) some dissimilar text genres, this would require the design of a specific and profound study. The surplus of scribal variants (or allographs) across the corpus is now a matter of public scholarly record. One of the possible reasons for their incidence is that during the hours-long carving sessions, various scribes worked off their tensions through aesthetic and "playful" glyphic choices. An interesting piece of information regarding the assumed time spent on engraving artifacts is possibly found in Albert van Hoorebeeck. ${ }^{23}$ Whilst discussing a false tablet (= a replica of the original tablet "Keiti"), he ${ }^{24}$ clarifies that the work on that object owes to the modern Belgian investigator F(rançois) Dederen. ${ }^{25}$ Van Hoorebeeck ${ }^{26}$ later reveals, "The author [= Dederen], otherwise satisfied with that fake [= imitation; our note], had dedicated some 160 hours of work, using an instrument on whose nature he preferred to keep silence [...]. We can imagine - incorrectly - the time the [premissionary; our note] Rapanui spent in carving their tablets". Although the information on the true antecedents is inaccessible, it is reasonable to state that unlike machines, humans are unable to perform extremely repetitive tasks with a low rate of error. ${ }^{27}$ Translated into the context of the classical rongorongo script, it means that a single or an (especially) complex glyph could not be identically carved fifty or eighty times along a text of 1000 , 2000, or 3000 elements. Whether in terms of invested time or efforts, we feel that the former rongorongo scribes found the pictorial-like nature (= design) of many glyphs

\footnotetext{
22 This glyphic design 5 ล 2 . is printed in MÉTRAUX, A. Two Easter Island Tablets in Bernice Pauahi Bishop Museum, Honolulu, p. 2, FIG. 2; cf. also FISCHER, S. R. Rongorongo: The Easter Island Script, History, Traditions, Texts, p. 461, RR 12a3.

${ }^{23}$ VAN HOOREBEECK, A. La Vérité sur l'Ile de Pâques, pp. 268-269.

${ }^{24}$ Ibid., p. 269.

${ }^{25}$ For an update on the work of the Belgian artist and connoisseur, one should refer to DEDEREN, F. Ille de Pâques: L'Origine de l'Écriture rongorongo, especially to Figures 5 and 14.

${ }^{26}$ VAN HOOREBEECK, A. La Vérité sur l'Ile de Pâques.

27 cf. SANKOFF, D., KRUSKAL, J. Time Warps, String Edits, and Macromolecules: The Theory and Practice of Sequence Comparison, p. 9; GARRETT, P. Making, Breaking Codes: An Introduction to Cryptology, p. 46; STOKES, P. A. Computer-aided Palaeography, Present and Future, pp. 324-325. In mentioning the "digital" aspects versus the "humanities" requirements in the automatic documentation of medieval manuscripts, STOKES, P. A. ibid., considers the following, "Certainly any system must allow for a lot of scribal variation. Manuscripts are written by people, not machines, and people change according to many different factors, so this must be taken into account by any paleographical method, digital or otherwise".
} 
"costly". ${ }^{28}$ Consider here the "kinetic"- / rhythmic-like sequence attested on Cb9-10 (= $\mathrm{C} v 9-10) ;{ }^{29}$ having an apparent resemblance to an "animated clip" the carving of said sequence would have not been trifling, requiring imagination and also a particular skill set. On the other hand, using a computer keyboard, the letter " $O$ " or the ligature " $E$ " can be printed in a tedious and most correct fashion over a text of relative length. One may realize by now the overall contrast between the two scenarios if we recall that the RR scribes had to use differently shaped slabs and sticks of wood with uneven surfaces as the writing medium, along with obsidian gravers / flakes ${ }^{30}$ and a shark's tooth to calibrate and render the glyph-forms.

At this point, we shall revisit a hypothesis on the meaning of glyph $/ 670 /$, the so-called "manu moe" [sleeping bird]. The basic reference is the "rhythmic"-

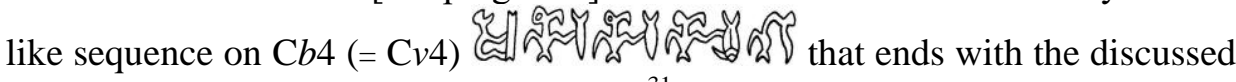
"bird"-like glyph. In Harris and Melka ${ }^{31}$ it is shown that the /670/-related sources hark back to Metoro's "readings". ${ }^{32}$ Sober scholars have doubted (even dismissed) the value of such "readings" - for details, one should look at Alfred Métraux; Steven R. Fischer's Chapter 9, "Bishop Jaussen and Metoro Tau'a Ure", and Jacques B. M. Guy. ${ }^{33}$ Although the present authors disapprove Metoro's translations in consonance with Métraux, Fischer, Guy, and other

${ }^{28}$ For more on the topic, see MELKA, T. S., ALTMANN, G. Script Complexity: A Case Study. Specifically, as far as our own experience with the rongorongo inscriptions goes, it may be reported that various scribes spent time lavishing details on many complex glyph-forms; cf. e.g., the "Santiago Staff"; "Great St Petersburg Tablet"; "Aruku Kurenga Tablet"; "Tahua Tablet"; "Small Washington Tablet"; "Small Santiago Tablet"; "Keiti Tablet"; "Great Washington Tablet"; "London rei miro 9295" (= La).

29 cf. MELKA, T. S. On a "Kinetic"-like Sequence in rongorongo Tablet "Mamari", p. 62, Figure 3.

30 cf. MELKA, T. S., SCHOCH, R. M. Exploring a Mysterious Tablet from Easter Island: The Issues of Authenticity and Falsifiability in rongorongo Studies, p. 525, Figure 12.

${ }^{31}$ HARRIS, M., MELKA, T. S. The Rongorongo Script: On a Listed Sequence in the recto [verso; repaired] of Tablet 'Mamari', Part I, p. 140.

32 cf. IMBELLONI, J. Las 'Tabletas Parlantes' de Pascua, Monumentos de un Sistema Gráfico Indo-oceánico [The 'Talking Tablets' of Easter Island, Monuments of an IndoOceanic Graphic System], p. 142, Fig. 12, \# 49; BARTHEL, T. S. The "Talking Boards" of Easter Island, p. 64; BARTHEL, T. S. Rongorongo-Studien (Forschungen und Fortschritte bei der Weiteren Entzifferung der Osterinselschrift), p. 408; here we include also KRUPA, V. The Symbol for Lizard in the Writing of Easter Island, p. 63.

33 MÉTRAUX, A. Ethnology of Easter Island; FISCHER, S. R. Rongorongo: The Easter Island Script, History, Traditions, Texts; GUY, J. B. M. Peut-on se Fonder sur le Témoignage de Metoro pour Déchiffrer les Rongo-Rongo? 
scholars, Fischer's short insertion "[...] they yield perhaps at best only occasionally correct sign "identifications", ${ }^{34}$ leads us to critically assess the assigned value of $/ 670 /$. The "sleeping bird" by extension was allegorically associated with slumber, waning, demise, and death. Reprising Barthel, the Slovak scholar Viktor Krupa posited that /670/ 2 "refers [...] not only to sleeping but also to other related states or processes, i.e. dying, lying down, falling down, etc." ${ }^{35}$ Harris and Melka performed a complex analysis of glyphs /670/ and /700/ (plus variants) in several environments, forwarding eventually the hypothesis that the $\mathrm{C} b 4(=\mathrm{C} v 4)$-sequence might encode a magical charm formula, or the section of a war song. ${ }^{36}$ The said analysis was based on structural, statistical, and the available linguistic and ethnographic data; the weight of the cumulative evidence pointed at such direction(s).

The occurrence of the " $L-T$ " glyph offers an intriguing frame to test again the hypothesis. If the remaining piece of wood was part of the handle / shaft of a hand-weapon, of a throwing projectile, or a ritual-based tool, ${ }^{37}$ it would make sense for a pre-missionary Rapanui macho to etch a martial accessory with the glyph that symbolized "death" / "knocked out". Charged with mana, the glyph could act as a magical amulet under determined circumstances ${ }^{38}$ The ritualistic

${ }^{34}$ FISCHER, S. R. Rongorongo: The Easter Island Script, History, Traditions, Texts, p. 53; Earlier, ROUTLEDGE, K. (Mrs. SCORESBY ROUTLEDGE), The Mystery of Easter Island, p. 253, expressed a similar concern along these lines, "The names which Bishop's informant [= Metoro (i.e., Melchor) Tau'a Ure; our note] assigned to some five hundred figures may or may not be accurate, but whether the native or anyone else could have stated what the signs conveyed is another matter"; and on the same topic, BARTHEL, T. S. Pre-contact Writing in Oceania, p. 1181, states, "[...] the Metoro songs are not the actual key [to decipherment; our note] but the raw material for the interpretation of a certain percentage of the RR signs". Whatever value "Metoro songs I chants" may have (or not) for the present-day researcher we cannot rub out the fact that future pieces of evidence may be of decisive importance for their re-assessment.

${ }^{35}$ KRUPA, V. The Symbol for Lizard in the Writing of Easter Island, p. 63.

${ }^{36}$ HARRIS, M., MELKA, T. S. The Rongorongo Script: On a Listed Sequence in the recto [verso; repaired] of Tablet 'Mamari'. Part I, Part II.

${ }^{37}$ Possibly used in rituals involving the sacrifice of human victims to the local deities and cannibalism; see EDWARDS, E., EDWARDS, A. When the Universe was an Island: Exploring the Cultural and Spiritual Cosmos of Ancient Rapa Nui, pp. 275-276.

${ }^{38}$ See THOMSON, W. J. Te Pito te Henua, or Easter Island, pp. 469-470; MÉTRAUX, A. Ethnology of Easter Island, p. 339; POZDNIAKOV, K. Les Bases du Déchiffrement de l'Écriture de l'Ile de Pâques, p. 299, suggesting that "mini-texts" in the RR corpus might deal with "magic formulas", among other things; FISCHER, S. R. Rongorongo: The Easter Island Script, History, Traditions, Texts, pp. 315-317. The inserted terms "determined circumstances" should not be taken here as "large-scale conflicts" or 
The Quest for Information Retrieval - Part II

function of the " $L-T$ fragment" remains a valid option, if we reflect, for instance, on Andy Mills's lines, "Weaponry permeated a wide range of cultural contexts in Polynesia, and performed a multitude of roles. The non-combative contexts of weapon use in historical Polynesia amounted to an equal or greater role than actual combat; so it would be an inaccurate representation to blankly [and completely; our note] view them as tools for killing". ${ }^{39}$

On the purely practical side - whether the " $L-T$ " original artifact had ceremonial $^{40}$ or utilitarian functions -, the embedded power aimed at boosting the fighting skills as well as the bravery of the unknown ancient owner. Yet, one should not get the impression that rongorongo signs conveyed exclusively practices related to magic (of the sympathetic kind or not); that reminds us of Ignace J. Gelb's description of RR boards as "[...] a series of pictorial representations concocted for magical purposes" ${ }^{41}$ Research records show that the script consists of other additional text categories and sub-categories. ${ }^{42}$

"pitched battles", rather than as "casual and violent encounters" or "ambush situations". ROUTLEDGE, K. (Mrs. SCORESBY ROUTLEDGE). The Mystery of Easter Island, p. 224, comments upon the internecine fights / battles in the following terms, "The warfare consisted largely of spasmodic and isolated raids; an aggrieved person gathered together his neighbours and descended on the offenders". Another description of the erstwhile "battles" is found in BROWN, J. M. The Riddle of the Pacific, p. 215, "When the battle did occur it was what we would call a riot or a scrimmage; there was neither order nor tactics in it. Every warrior hit where he could and killed as many as he had opportunity to kill".

${ }^{39}$ MILLS, A. Violent Encounters: Historical Notes on the Curatorial Representation of Polynesian Weapons, p. 187.

${ }^{40}$ Ibid., p. 188, notes that "Elaborate mock battles also occurred in historical Polynesia as pivotal scenes of annual state ritual". MILLS's observation in Violent Encounters: Historical Notes on the Curatorial Representation of Polynesian Weapons may also provide a glimpse into the ceremonial scope of the artifact under discussion.

${ }^{41}$ GELB, I. J., WHITING, R. M. Methods of Decipherment, p. 100; for a reaction, see FISCHER, S. R. Rongorongo: The Easter Island Script, History, Traditions, Texts, p. 618 , note 4 .

${ }^{42}$ See ROUTLEDGE, K. (Mrs. SCORESBY ROUTLEDGE). The Mystery of Easter Island, pp. 248-249; ENGLERT, S. La Tierra de Hotu Matu'a: Historia, Etnología y Lengua de la Isla de Pascua [The Land of Hotu Matu'a: History, Ethnology, and Language of Easter Island], pp. 321-322; IMBELLONI, J. Las 'Tabletas Parlantes' de Pascua, Monumentos de un Sistema Gráfico Indo-oceánico [The 'Talking Tablets' of Easter Island, Monuments of an Indo-Oceanic Graphic System], pp. 134-136; BUTINOV, N. A., KNOROZOV, Y. V. Preliminary Report on the Study of the Written Language of Easter Island, pp. 8-9; BARTHEL, T. S. Pre-contact Writing in Oceania, pp. 1168, 1176-1177; FISCHER, S. R. Rongorongo: The Easter Island Script, History, Traditions, Texts, pp. 331-333. 
Consider for now that entwining the practice of writing with magical empowerment is no privilege of a single culture. The topic is treated by many authors covering various real-world scribal traditions, and readers wishing to come to grips with it may refer e.g., to Quibell; Schott; Tambiah; Drogin; and Strubbe.$^{43}$ We should also admit that deciphering and interpretative matters are subject on many grounds to regular contesting in the rongorongo studies. To see if the hypothesis regarding the " $L-T$ " artifact sums up to something beyond a tentative suggestion, we shall have to systematically analyze and capture the interplay between glyphs of the /600/-series and their environments in the extant corpus. The possible emergence of any other genuine artifact displaying RR glyphs of the /664/- and /674/-type, plus other contiguous glyphs, will be even better for clearing any speculative nonsense and sticking to the facts (v. supra).

\section{Hypotheses}

Given a number of tangible premises, hypotheses are expected regarding the artifact comprising the individually distinct " $L-T$ " glyph. Before ascribing them, it may be suspected that the fragment was removed in order to preserve the glyph, while the rest of the object was perhaps reused for some other purpose or destroyed.

At this point we wish to underscore (that) the English-based terminology intent on describing or paralleling the indigenous Rapanui weapons may often fall short. We are aware of the "reductive discursive impact of the terms [...]" as they may devaluate the "[...] Polynesian weapons [and their ingrained mana force; our note] through false-neutral nomenclature". ${ }^{45}$ Yet, despite the lack of truly comparable matches, such terminology is offered for practical and orientating reasons. ${ }^{46}$

(1) In view of the size (approximately $3.7 \mathrm{~cm}$ by $3.4 \mathrm{~cm}$ by $2.5 \mathrm{~cm}$ in maximum dimensions) and the cylindrical-like shape (Fig. 1), our perceptional and

${ }^{43}$ QUIBELL, J. E. The Ramesseum and the Tomb of Ptahhetep; SCHOTT, S. Symbol und Zauber als Grundform altägyptischen Denkens; TAMBIAH, S. J. The Magical Power of Words; DROGIN, M. Biblioclasm: The Mythical Origins, Magic Powers, and Perishability of the Written Word; STRUBBE, J. H. M. Cursed Be He that Moves My Bones.

${ }^{44}$ MILLS, A. Violent Encounters: Historical Notes on the Curatorial Representation of Polynesian Weapons. p. 197.

45 Ibid., p. 192.

46 cf. MELKA, T. S., SCHOCH, R. M. The Quest for Information Retrieval: An Inscribed Relic from Ancient Rapa Nui (Easter Island), Part I, p. 143, note 26. 
The Quest for Information Retrieval - Part II

cognitive abilities link the " $L-T$ fragment" with the shaft / handle of some sort of club, hand weapon, or similar implement. The range and the width of the " $L-T$ fragment" appear, however, too small to have been part of a staff or club per se (such as an $u a$ staff or a paoa club $^{47}$ for use at close quarters), although perhaps it could have been the end of a long and thin staff. The initial assessment is that the " $L-T$ Fragment" is the remains of a handle that was once attached to some sort of obsidian spear-point or knife blade ${ }^{48}$ (see e.g., Figs. 3 and 4). We think of the mata $a /$ mata $^{49}$ (the broad-faced stemmed obsidian "blade"; Figs. 5 and 6) here, but it could also have been attached to some other

${ }^{47}$ On the short-handled clubs called paoa, see e.g., BROWN, J. M. The Riddle of the Pacific, p. 211; SKINNER, H. D. On the patu Family and its Occurrence beyond New Zealand, p. 189, Figs. 18 and 19; MÉTRAUX, A. Ethnology of Easter Island, p. 169, p. 170, Figure 6; ENGLERT, S. La Tierra de Hotu Matu'a: Historia, Etnología y Lengua de la Isla de Pascua [The Land of Hotu Matu'a: History, Ethnology, and Language of Easter Island], p. 133; KJELLGREN, E. Splendid Isolation: Art of Easter Island, p. 45, no. 45. Club (paoa); cf. also KJELLGREN, E. Oceania: Art of the Pacific Islands in the Metropolitan Museum of Art, hand club, \# 190, pp. 312-313.

${ }^{48}$ See also MÉTRAUX, A. Ethnology of Easter Island, p. 165; ENGLERT, S. La Tierra de Hotu Matu'a: Historia, Etnología y Lengua de la Isla de Pascua [The Land of Hotu Matu'a: History, Ethnology, and Language of Easter Island], p. 133, on the so-called "kakau" (cutting obsidians tied to a short wooden shaft) and "mata' a kohau" (spears, made of hau hau [Triumfetta semitriloba] or mahute [Broussonetia papyrifera] wood, ending with an obsidian tip); cf. LELIÈVRE, F., POTHIER, L., et al. Easter Island: An Epic Voyage, p. 33, \# 9. In DEDEREN, F. Corpus Rapa Nui. Inventaire Mondial de la Statuaire en Bois de l'île de Pâques, p. 41, under Série 08, DIADÈMES \& GUERRIERS [Series 08, HEAD-CROWNS \& WARRIORS], we run across a pair of cranial engravings: one made on a tangata statuette (Hooper: 373), and the next on a (mo'ai) kava kava (Peabody Salem E5308 / 2420). These human-like designs hold in their hands what can be described as "mata'a kohau". And on some bark-cloth sculptures from Easter Island similar implements are shown, apparently imitating or modeling tattoo patterns; see KAEPPLER, A. L. Sculptures of Barkcloth and Wood from Rapa Nui, Figs. 31 and 65; see also KAEPPLER, A. L., VAN TILBURG, J. A. The Iconic Tattooed Man of Easter Island, Figs. 17 and 19.

${ }^{49}$ RAmíReZ AliagA, J. M. Rapanui Mataa, A Simple Artifact with a Complex History, Introduction: A Phonetic Note, p. 367, discusses the insertion of the term "mataa $(=$ matā $)$ " versus "mata' $a$ ". Since the relatable literature has constantly delved into them in one form or another, we make use of either in this study, admitting in the end they refer to the same class of pre-missionary artifacts / multifarious contexts. FUENTES, J. Diccionario y Gramática de la Lengua de la Isla de Pascua. PascuenseCastellano, Castellano-Pascuense. Dictionary \& Grammar of the Easter Island Language. Pascuense-English, English-Pascuense, p. 785, offers the following definition of the term: "matá n. obsidian / vitreous lava / the spear heads made from this stone". 
type of blade. Comments on "kakau" (der Wurfspeer = launching spear / javelin) and "vero" (der Spieß = lance) are also included in subsection c) "Waffen" (Weapons) [Chapter 15, Ethnographica, Interpretation] of Barthel. Deriving from Metoro's chants, glyph /86/ $\widehat{\uparrow}_{\text {would denote an obsidian-tipped }}$ stick. ${ }^{50}$ It is clear that this glyph strikes an iconic resemblance with the weapon in question; now, if we should trust forthrightly Metoro for all his readings this is altogether another issue (v. supra).

Yet, the pre-contact to missionary era internecine feuding and sporadic skirmishes (before 1722 to circa 1864 - early 1870s, respectively), together with obsidian-based tools of warlike and other uses, ${ }^{51}$ are frequently mentioned in the literature. ${ }^{52}$ Similarly, the obsidian, as an important local commodity,

${ }^{50}$ BARTHEL, T. S. Grundlagen zur Entzifferung der Osterinselschrift. (Abhandlungen aus dem Gebiet der Auslandskunde 64, Reihe B), pp. 294-295.

${ }^{51}$ As other authors have noted, one can view the "[...] other uses" of mata' $a$ (= matā) related to activities such as food processing via scraping and cutting; land cultivation; creating, sharpening and/or drilling bone or shell tools; rough and/or fine woodworking; and potential ritual scarification; cf. SKOTTSBERG, C. Part I. Notes on a Visit to Easter Island. In The Natural History of Juan Fernandez and Easter Island, p. 16, Plate 14; ROPITEAU, A. Une Visite au Musée Missionnaire des Pères des Sacrés-Coeurs de Picpus à Braine-le-Comte (Belgique), p. 522; BOLLT, R., CLARK, J., FISHER, P., YOSHIDA, H. An Experiment in the Replication and Classification of Easter Island mata'a, p. 125; LELIÈVRE, F., POTHIER, L., et al. Easter Island: An Epic Voyage, p. 33; LIPO, C. P., HUNT, T. L., HORNEMAN, R., BONHOMME, V. Weapons of War? Rapa Nui mata'a Morphometric Analyses; KONONENKO, N., STEVENSON, C. M., et al. The Many Uses of matā on Rapa Nui; DiNAPOLI, R. J., LIPO, C. L., HUNT, T. L. Revisiting Warfare, Monument Destruction, and the 'Huri Moai' Phase in Rapa Nui (Easter Island) Culture History.

${ }^{52}$ See PHILIPPI, R. A. La Isla de Pascua i sus Habitantes. Jeografía [Easter Island and its Inhabitants. Geography], p. 390; GEISELER, W. (Kapitänlieutenant). Geiseler's Easter Island Report: An 1880s Anthropological Account, p. 65; THOMSON, W. J. Te Pito te Henua, or Easter Island, pp. 472, 474-476, Plate LVII; SELIGMAN, C. G. Note on an Obsidian Axe or Adze Blade from Papua, pp. 161-162, Fig. 2; BALFOUR, H. Some Ethnological Suggestions in regard to Easter Island, or Rapanui, p. 357; ROUTLEDGE, K. (Mrs. SCORESBY ROUTLEDGE). The Mystery of Easter Island, pp. 223-224, 268, 271; BROWN, J. M. The Riddle of the Pacific, pp. 210-212; ROPITEAU, A. Une Visite au Musée Missionnaire des Pères des Sacrés-Coeurs de Picpus à Braine-le-Comte (Belgique), p. 522; MÉTRAUX, A. Ethnology of Easter Island, pp. 165-170, 280-281; ENGLERT, S. La Tierra de Hotu Matu'a: Historia, Etnología y Lengua de la Isla de Pascua [The Land of Hotu Matu'a: History, Ethnology, and Language of Easter Island], pp. 128-136; ENGLERT, S. Island at the Center of the World: New Light on Easter Island, pp. 137-145; BARTHEL, T. S. Obsidianwaffen von der Osterinsel; BÓRMIDA, M. Formas y Funciones del "Matá", el 
appears in a short recitation related to kai-kai string figures. ${ }^{53}$ Although the authenticity of its pre-1864 status is uncertain, ${ }^{54}$ it shows the concern of the natives toward the artifact / material, or it may hint at fossilized records in their collective memory. The recitation is reproduced below in its original form, Rapanui and German; ${ }^{55}$ plus the English version rendered by the present authors.

\begin{tabular}{|c|c|c|}
\hline Rapanui & German & English \\
\hline $\begin{array}{l}\text { mataa nui } \\
\text { a raka e }\end{array}$ & $\begin{array}{l}\text { Die große Obsidianspitze } \\
\text { gehört Raka }\end{array}$ & $\begin{array}{l}\text { The large obsidian spear-point } \\
\text { belongs to Raka }\end{array}$ \\
\hline $\begin{array}{l}\text { mataa iti } \\
\text { a roro piapia }\end{array}$ & $\begin{array}{l}\text { Die kleine Obsidianspitze } \\
\text { gehört Roro-Piapia }\end{array}$ & $\begin{array}{l}\text { The small obsidian spear-point } \\
\text { belongs to Roro-Piapia }\end{array}$ \\
\hline
\end{tabular}

Más Conocido Artefacto de la Arqueología de Pascua [Shapes and Functions of "Matá", the Most Well-known Archaeological Artifact of Easter Island]; EMORY, K. P. East Polynesian Relationships as Revealed Through Adzes; McCOY, P. Easter Island, pp. 149-151, Figure 6.7; BELLWOOD, P. Man's Conquest of the Pacific: The Prehistory of Southeast Asia and Oceania, p. 373; EDLER, J. C. Art of Polynesia, p. 11; McCALL, G. Rapanui: Tradition and Survival on Easter Island, p. 38; MAIANI, M., QUER, S. Voyage vers l'île Mystérieuse de la Polynésie a l'Île de Pâques 20 Avril - 15 Septembre 1996, p. 187, Figures 149-153; SIMPSON Jr., D. F. Captain A. W. F. Fuller's Contribution to The Field Museum's Easter Island Collection, p. 25, Figure 10; LELIÈVRE, F., POTHIER, L., et al. Easter Island: An Epic Voyage, p. 33, assorted mata' $a$ / matā 1-8 (held at The Royal Museums of Art and History, Brussels); HICKS, D., HAMILTON, S., et al. Easter Island and Pitcairn Island, p. 568, regarding mata ${ }^{6}$ / $m a t \bar{a}$ and stone toki held at The Pitt Rivers Museum (Oxford, England); FLAS, D. The Mata'a and the "Collapse Hypothesis"; BAHN, P. The End of the Moai - Did they fall or were they pushed?; LIPO, C. P., HUNT, T., et al. Weapons of War? Rapa Nui mata'a Morphometric Analyses, p. 175, Figure 2; KONONENKO, N., STEVENSON, C. M., et al. The Many Uses of matā on Rapa Nui.

${ }^{53}$ See BARTHEL, T. S. Rezitationen von der Osterinsel, p. 843, $d$.

${ }^{54}$ For a critical evaluation of the native "oral histories and traditions" as recorded by the first ethnographers, see DiNAPOLI, R. J., LIPO, C. L., HUNT, T. L. Revisiting Warfare, Monument Destruction, and the 'Huri Moai' Phase in Rapa Nui (Easter Island) Culture History, pp. 15-16.

${ }^{55}$ BARTHEL, T. S. Rezitationen von der Osterinsel, p. 843, $d$. 
Olaf Blixen ${ }^{56}$ reprises the same short lines of this kai-kai song-type and produces different finds,

Rapanui: Matā nui a raka e;

Spanish: Matá grande bien pulido (= de superficie lisa);

English: [The large obsidian spear-point (is) well-polished (= of even surface)]

Rapanui: Matā iti a roro piapia.

Spanish: Matá pequeño, cerebro en papilla.

English: [The small obsidian spear-point smashes the brains]. ${ }^{57}$

Although both versions of translation differ to an extent from each other, what matters at this point is the realization of an indirect evidence of fighting (or of a preparatory stage for skirmishing).

In order to be technically rigorous, we focus at this point on the article of Lipo, Hunt, et al. ${ }^{58}$ Their useful conclusions that "[...] mata'a do not appear to be related to systemic warfare where performance as lethal weapons would be paramount", and that "[...] mata'a had more than one function is not surprising" give food for thought. An important aspect of their study, in our opinion, is that they apparently considered only the broad-faced stemmed obsidian blades, which have been found very abundantly on Easter Island. Otherwise, rarer forms of other obsidian-tipped weapons, such as hafted true points ("spear points" attached to handles / shafts) ${ }^{59}$ and knives $\left(=k a^{6} i\right.$, a sharpened stone knife $)^{60}$ - examples of which are illustrated in Figs. 3, 4, 7, and

56 BLIXEN, O. Figuras de Hilo Tradicionales de la Isla de Pascua y sus Correspondientes Salmodias [Traditional String Figures from Easter Island and their Corresponding Recitations], p. 69.

57 Ibid., p. 69, note 1, offers various arguments for the revision of BARTHEL's Rezitationen von der Osterinsel, p. 843, $d$, earlier translation.

${ }^{58}$ LIPO, C. P., HUNT, T., et al. Weapons of War? Rapa Nui mata'a Morphometric Analyses.

${ }^{59}$ An image of a relatively well-preserved spear having an obsidian point (mata' $a$ ) is shown at LELIÈVRE, F., POTHIER, L., et al. Easter Island: An Epic Voyage, p. 33, \# 9. Note here the use of a tang, to assist in the hafting of the obsidian onto the long wooden shaft. The artifact is part of the collections of the Peabody Museum of Archaeology and Ethnology, Harvard University (Cambridge, Massachusetts, USA).

${ }^{60}$ See e.g., DU FEU, V. Rapa Nui (Lexicon), p. 206, regarding entry "5.2.140 sharp ka“ $i$ ka' $i$ ", and FUENTES, J. Diccionario y Gramática de la Lengua de la Isla de Pascua. 
The Quest for Information Retrieval - Part II

13a, b, c - ${ }^{61}$ were not documented for analysis. (At this juncture, since we strongly suspect that the "Lutz-Terasaki fragment" was part of a handle or shaft for an obsidian-tipped or bladed implement, it might be worth including an illustration of a non-lithic spear point [made of bone]; see Figs. 14a and 14b. The little material that remains of the "Lutz-Terasaki fragment" is, we estimate, thicker than the "missing" shaft for this bone spear point. We believe the discussed artifact is a fine and rare example - fine because of the overall craftsmanship, and rare because bone spear tips did not easily survive, unlike obsidian stone artifacts. $)^{62}$

Returning to the course of lithic artifacts: the more pre-missionary Rapanui pieces we look into, we come to realize that mata $^{\prime} a$ / mata (broad-stemmed obsidian blades) are typically much "cruder" than the obsidian projectile head having a spear point-like shape or the obsidian tool (Figs. 3 and 7), which are finely worked. Similarly, while we are open to the possibility that broad-faced stemmed obsidian blades were not primarily instruments of violence, they could have gained such a role given the conflictive circumstances and flaring tempers (cf. Figs. 5 and 6; and A. Métraux, ${ }^{63}$ "Wars [= scuffles / feuds among natives; our note] were frequent and arose from the merest trifles, the principal causes being personal revenge, jealousy, greediness, and want"). George H. Cooke, a crew-member of the Expedition of the U.S.S. Mohican Survey of Easter Island, December 1886, evaluated the character and disposition of the local people as follows, "They are a bright, intelligent, quick-witted people, of rather a nervous temperament; tractable and gentle in disposition, decidedly sympathetic and tenderhearted and markedly emotional in their natures, so that they are easily moved either to tears or laughter".

Pascuense-Castellano, Castellano-Pascuense. Dictionary \& Grammar of the Easter Island Language. Pascuense-English, English-Pascuense, p. 754, "ká?i ká?i adj. sharp // n. edge / thread of a screw // vt. to sharpen // Mayaia Is. kái kái: to cut)".

${ }^{61}$ FLAS, D. The Mata'a and the "Collapse Hypothesis", p. 68, appears to address both possibilities (though favoring the basic hypothesis that "Use as a weapon is unlikely for most of the mata'a".) Two of his concluding remarks follow, "- Precise and reliable testimonies about the mata'a used as spearheads are more than scarce [...] - Clearly, very few of them could have been designed to be effective projectile heads, most of them being neither symmetrical nor pointed, and often heavy".

62 The "bone spear point" bereft of its "shaft" is included in the section PLATES (Figs. $14 \mathrm{a}$ and $14 \mathrm{~b}$ ) for the sake of completeness and comparative evaluations.

${ }^{63}$ MÉTRAUX, A. Ethnology of Easter Island, p. 149.

${ }^{64}$ COOKE, G. H., Te Pito te Henua, known as Rapa-Nui, commonly called Easter Island, South Pacific Ocean, p. 714; the underlining is made by the present authors for emphatic purposes. 
Unsurprisingly, that perceived emotionality may have represented a vector for mood swings, translated in due course into quarrels and other antagonizing episodes.

It is also admitted that the different types of modern knives are mostly designed either as eating utensils or kitchen utensils; however, they can be used as harmful weapons even if they were not intended as such; in like manner, as tempers fray, baseball or cricket bats designed primarily for sporting and recreational activities can be used as improvised impact weapons (see, in this respect, Paul Bahn's, Robin Torrence's, and J. M. Ramírez Aliaga's comparable remarks). ${ }^{65}$

More to the point, genuine injuries during such fighting have been documented via studies of the skulls and skeletons of Rapanui, including in some cases injuries caused by obsidian-tipped weapons as evidenced by fragments of obsidian that remained embedded in the surrounding bone. ${ }^{66}$ In a culture little beyond the Neolithic, the functional status of the " $L-T$ " artifact may be seen in two ways: as a mêlée weapon made use of (1) in real scuffles, or employed (2) in ritual and celebratory events. Furthermore, on a pan-Oceanic note, the widespread presence of arrays of weaponry or of "military" footprints are not unprecedented; see Thomas Williams; Friedrich August Karl von Specht; Friedrich Christmann and Richard Oberländer; James Edge-Partington and Charles Heape; Elsdon Best; Leopold A. D. Montague; Karl von den Steinen; B. A. de Vere Bailey; Carol S. Ivory; Jeff Evans; Eric Kjellgren; and Andy Mills. ${ }^{67}$

${ }^{65}$ BAHN, P. The End of the Moai - Did They Fall or Were They Pushed?, pp. 146-147; TORRENCE's, R. opinion is found in BOWER, B. Easter Islanders Made Tools, Not War. Artifacts Challenge Idea that Violence led to Rapa Nui Collapse, p. 11; RAMÍREZ ALIAGA, J. M. Rapanui Mataa, A Simple Artifact with a Complex History, pp. 375-376.

${ }_{66}$ GILL, G. W., OWSLEY, D. W. Human Osteology of Rapanui, p. 58, Fig. 56b; OWSLEY, D. W., BARCA, K. G., SIMON, V. E., GILL, G. W. Evidence for Injuries and Violent Death. We think that KAVANAGH, C., in Did Easter Island Culture Collapse? The Answer Is Not Simple, is quite reflective of how the controversy of the mata"a (fit for "stabbing" and "piercing") versus the mata"a (poor for "stabbing" and "piercing") may be treated, "The crucial point is that such debates continue, and can almost never be settled by a single study or analysis of a single type of artefact".

${ }^{67}$ WILLIAMS, T. Fiji and the Fijians: The Islands and their Inhabitants; SPECHT, F. A. K. von, Geschichte der Waffen: Nachgewiesen und Erlautert durch die Kulturentwickelung der Völker und Beschreibung ihrer Waffen aus allen Zeiten; CHRISTMANN, F., OBERLÄNDER, R. Ozeanien, die Inseln der Südsee. Aeltere und neuere Erforschungsreisen im Gebiete der Inselgruppen des Stillen Ozeans; EDGEPARTINGTON, J., HEAPE, C. An Album of the Weapons, Tools, Ornaments, Articles 
The Quest for Information Retrieval - Part II

If we care to expand a little, visitors, ethnologists, and archeologists have reported on the use of toki (mainly heavy picks, hammerheads, and adzes) as traditional carving and scraping instruments, knapped from hard local lavas (see Thomson; Routledge; Skottsberg; Brown; Métraux; McCoy; Bollt, Clark, et al.; Lelièvre, Pothier, et al.; Hicks, Hamilton, et al.; plus Figs. 8, 9, 10a, 10b, and 11a, 11b). ${ }^{68}$ William J. Thomson, ${ }^{69}$ among the native weapons in offensive and defensive operations, also mentions the "throwing-stones" hurled "[...] with great precision and accuracy from the hand". Grant McCall reveals a similar episode, "La Perouse experienced some pelting by stones in 1786 when some of his crew attempted to recover a grapnel stolen from the ship $[\ldots] "{ }^{70} \mathrm{Had}$ the circumstances arisen, a number of toki could have easily been transformed into warlike missiles and cause blunt or even lethal traumas during the running feuds or the skirmishes with the strangers. ${ }^{71}$

of Dress, \&c., of the Natives of the Pacific Islands; BEST, E. Notes on the Art of War, as Conducted by the Maori of New Zealand, with Accounts of Various Customs, Rites, Superstitions, \&c., Pertaining to War, as Practised and Believed in by the Ancient Maori. Part III; MONTAGUE, L. A. D. (Lieut.-Col.) Weapons and Implements of Savage Races (Australasia, Oceania, and Africa); VON DEN STEINEN, K. Die Marquesaner und Ihrer Kunst; DE VERE BAILEY, B. A. Notes on Oceanian War Clubs; IVORY, C. S. Marquesan ' $U$ ' $u$ [= war clubs; our note]: A Stylistic and Historical Review (take notice, however, that the ' $u$ ' $u$ clubs might have conveyed mostly an image of status and prestige; our note); EVANS, J. Maori Weapons in PreEuropean New Zealand; KJELLGREN, E. Oceania: Art of the Pacific Islands in the Metropolitan Museum of Art; MILLS, A. Violent Encounters: Historical Notes on the Curatorial Representation of Polynesian Weapons.

${ }^{68}$ THOMSON, W. J. Te Pito te Henua, or Easter Island, Plate LVII; ROUTLEDGE, K. (Mrs. SCORESBY ROUTLEDGE). The Mystery of Easter Island; SKOTTSBERG, C. Part I. Notes on a Visit to Easter Island. In The Natural History of Juan Fernandez and Easter Island, p. 16, Plate 14; BROWN, J. M. The Riddle of the Pacific, to face p. 166; MÉTRAUX, A. Ethnology of Easter Island; McCOY, P. C. A Note on Easter Island, Obsidian Cores and Blades; BOLLT, R., CLARK, J., et al. An Experiment in the Replication and Classification of Easter Island mata'a; LELIÈVRE, F., POTHIER, L., et al. Easter Island: An Epic Voyage, p. $32 \rightarrow 1$ and 2. Basalt hammer stones, 3. Obsidian scraper; HICKS, D., HAMILTON, S., et al. Easter Island and Pitcairn Island. ${ }^{69}$ THOMSON, W. J. Te Pito te Henua, or Easter Island, pp. 474-475; cf. LIPO, C. P., HUNT, T., et al. Weapons of War? Rapa Nui mata'a Morphometric Analyses, p. 184.

${ }^{70}$ McCALL, G. European Impact on Easter Island: Response, Recruitment, and the Polynesian Experience in Peru, p. 91.

${ }^{71}$ Several historical sources reporting on rock throwing are mentioned in OWSLEY, D. W., BARCA, K. G., SIMON, V. E., GILL, G. W. Evidence for Injuries and Violent Death, pp. 224-225; cf. also BAHN, P. The End of the Moai - Did they fall or were they pushed?, p. 148; DiNAPOLI, R. J., LIPO, C. L., HUNT, T. L. Revisiting Warfare, 
That the " $L-T$ fragment" was once part of a handle of an obsidian-tipped weapon used in combat is based, thus far, on the grounds of the probable wood species ${ }^{72}$ its cylindrical-like shape, plus the patina commensurate with the old age. ${ }^{73}$ A valid argument with further impact on this hypothesis is the occurrence of the "bird"- / "human"-like glyph. In this sense, the relationship glyph (= applied symbol) $\leftrightarrow$ artifact (= context) must have been cogent and non-arbitrary. Rudolf Arnheim draws attention to the fact that "[...] the appearance of any element depends on its place and function in an overall pattern". ${ }^{74}$ As matrixglyph /670/ (and variants thereof) seems to respond in certain contexts to the notions of "demise", "waning" / "lowering", "slumber", and hence, "death", the original Rapanui owner (or a person with some scribal knowledge) etched the glyph on the handle / shaft. In this case, we have to assume the time-gap between the manufacturing of the handle and etching was almost coincident, or minor at least. Since magic had a powerful hold on pre-missionary life, the glyph was intent on increasing the effects of the weapon: its power to inflict harm on any target would be shown most fully.

(2) Other competing approaches are possible, such as relating the glyph / artifact to the name of the original owner. Glyph(s)/664/ कु $/ \mathrm{V} 460.77 / /^{75}$ (?) fragment" $3 \sqrt{3}$ - occur in texts that very likely encode lists of personal names in different formats and time divisions ( $\rightarrow \mathrm{I} a \cdot \mathrm{T} a \cdot \mathrm{G} v$ ). The human practice of tagging artifacts (for identification, ownership, rank) is recognized, and the high- or low-status individual of the " $L-T$ " relic would have been no exception.

Monument Destruction, and the 'Huri Moai' Phase in Rapa Nui (Easter Island) Culture History, p. 10.

${ }^{72}$ It may be Thespesia populnea / Pacific rosewood / mako' $i$, as discussed in Part I of our article.

73 Considering the object was previously owned by the Bernhard Lutz Family (Switzerland) and also by the New York dealer, collector, and connoisseur George Terasaki, the " $L-T$ fragment" may find (as such) a fitting reflection in the words of PATERSON, R. K. Collecting "Tribal Art" - Sacred or Secular?, p. 305, "The [nonWestern art; our note] market usually excludes contemporary material and places a premium on objects that show signs of traditional use or age".

74 ARNHEIM, R. Art and Visual Perception: A Psychology of the Creative Eye, p. 5.

75 This suggested code-number is found in BARTHEL, T. S. Grundlagen zur Entzifferung der Osterinselschrift. (Abhandlungen aus dem Gebiet der Auslandskunde 64, Reihe B), p. 59. 
One "little" concern is that texts $\mathrm{I} a \cdot \mathrm{T} a \cdot \mathrm{G} v$ include additional glyphs in their standard onomastic sequences, whereas the " $L-T$ " glyph is totally disjointed (= non-contiguous). Hapax phenomena, as we know, are difficult to study scientifically simply because there are no fully reliable and secure grounds to allocate and replicate the "lone" event. In principle, the problem tends to become clearer if we tackle rongorongo in cryptological terms: in those of text encryption and decryption. As Claude E. Shannon noted in one of his seminal articles, ${ }^{76}$ there is an inherent difficulty with (very) short ciphers, one that is independent of the solution method or language model used. A mathematical measure of the decipherment uncertainty was suggested by Shannon: equivocation, in his choice of words; nowadays known as entropy. Expanding further the topic, Sujith Ravi and Kevin Knight offer a plain heuristic case: given a short cipher like XYYX, we can never be sure if the answer is peep, noon, anna, etc. ${ }^{77}$ The difficulties are easily imagined with discrete symbols or very short strings of an unidentified script, especially if they are of unknown provenance and devoid of a context. Think of it another way: let us assume a pair of capital letters are found in the far future on a wrinkled scrap of paper and dated to the beginning of the twenty-first century: 〈C.R.〉. As these characters fit in the category of random information, they could necessarily be the equal representation of sundry words or even phrase-sets, and could transcribe English, French, Swedish, Welsh, Latin, Portuguese, German, Finnish [...]. Even if the search parameters are narrowed, $\rightarrow$ the capital letters transcribe Latin, they could be anything, from Carolus Rex [King Charles]; Civis Romanus [a Roman Citizen]; to Custos Rotulorum [Keeper of the Rolls / Records] - to mention a few possible keys.

Besides, we should wait until we get further data on glyph 35 from other contexts (existent or to be discovered; v. supra). Since the pre-missionary rongorongo scribes resorted as a matter of course to allegories and metaphors and encoded them in various glyphs, we could still take refuge in doubt when it comes to a precise decipherment. ${ }^{78}$ To demonstrate the point with a heuristic

${ }^{76}$ SHANNON, C. E. Communication Theory of Secrecy Systems.

77 RAVI, S., KNIGHT, K. Attacking Decipherment Problems Optimally with LowOrder N-gram Models, p. 818. Specifically, regarding the key equivocation observed (bits) versus cipher length (English letters = 1-gram, 2-gram, and 3-gram); see ibid. Attacking Decipherment Problems Optimally with Low-Order N-gram Models, p. 818, Figures 4, 5, and 6 .

${ }^{78}$ On re-inspection, we wish to point out that whether on part of committed and versatile scholars or serious aficionados, decipherments as such (combined with the inherent challenge and "detective appeal") have been too "juicy" to resist; cf. 
example from English: in popular conversation, one usually says "obvious" or "clear"; in academic speech, one may opt for "self-evident"; and in a metaphorical setting, a person may choose "as the sun at noonday". If the metaphor "as the sun at noonday" standing for "obvious" or "clear" is "arbitrarily" encoded via the discrete Wingdings symbol 105 ")(", a modern mind might not exactly pin down "[...] the sun at noonday". Otherwise, based on a nearly intrinsic relationship with the image, ${ }^{79}$ we may experience and better perceive a "shining sun" at noon and some of its metaphorical connotations ${ }^{80}$ by the Wingdings iconic-like sign $82 \rightarrow$ "

(3) If, on the other hand, the time-gap between the manufacturing of the artifact and its etching is more-than-minor or considerable, it would be difficult to sustain hypothesis No. 1. In this vein, anyone in the pre-1864 period could have added the inscription. The advantages gained by doing so may have paralleled or outweighed the importance of the artifact. A number of them follow: (a) add some extrinsic value to the current object; (b) the person behind it applied his aesthetic vision or tested his carving skills; (c) or, simply tagged it for practical reasons, e.g., as part of an appellation; affiliation to a descent group; identity mark; marking a weapon that had been used to kill someone in the past, etc.

Based on the examination of the evidence, the most reasonable hypothesis in our opinion is No. 1: the surviving " $L-T$ fragment" has the expected size for a handle of some sort of knife or other obsidian-pointed weapon or object, or perhaps, it could have been the end of a long and thin staff.

ROBINSON, A. Lost Languages: The Enigma of the World's Undeciphered Scripts, p. 319; MELKA, T. S. Some Considerations about the Kohau Rongorongo Script in the Light of a Statistical Analysis of the 'Santiago Staff', p. 57, footnote 76; SCHOCH, R. M., MELKA, T. S. The Rayitoki (Rangitoki) Bark-Cloth Piece: A Newly Recognized Rongorongo Fragment from Easter Island, p. 117, p. 132.

${ }^{79}$ In a broader context, for a characterization of a choice of "early" / ancient scripts making use of iconic / highly pictorial-like symbols; see VALÉRIO, M., FERRARA, S. Rebus and Acrophony in Invented Writing. Also, the observation of TAMARIZ, M., ROBERTS, S., et al. The Interactive Origin of Iconicity, p. 2, matches up well with our specific context, "[...] iconicity also plays a role in communication, during which it can help establish new conventional meaning-signal mappings".

${ }^{80}$ See e.g., FERBER, M. A Dictionary of Literary Symbols, entry: Sun, p. 209, "The sun is not only the most striking thing to be seen but the very condition of sight; light and seeing, some have argued, lie at the root of all symbolism".

${ }^{81}$ Cognitive scientists have taken a similar stand in this regard; see e.g., GARROD, S., FAY, N., LEED, J., OBERLANDER, J., MACLEOD, T. Foundations of Representation: Where Might Graphical Symbol Systems Come From?, pp. 963-965. 
The Quest for Information Retrieval - Part II

\section{Conclusions}

- Having the right kind of data in any corpus-based study allows deductions to take a turn towards plausibility, and later probability, thence towards certainty. ${ }^{82}$ This consideration notwithstanding, the genuine rongorongo corpus, while theoretically and practically insufficient, is what scholarship has available for analysis. Any other emerging context - short or relatively long -, bearing new, authenticated RR glyphs should be attached with importance and put to crosschecking. The " $L-T$ fragment" must be considered in this context.

- By all the more obvious signs, the " $L-T$ fragment" and its correlated glyph (Fig. 1) is an authentic cultural piece dating back to the pre-missionary era (that is, pre-1864). ${ }^{83}$ The various lines of investigation (wood species / patina / ethnographic and linguistic sources / structural and combinatory glyphic analyses) across this two-part article converge on this. As far as we are concerned, within this context, the ultimate scientific "payout" is the reconstruction and documentation of an indigenous relic.

- For the sake of clarity, we make one important observation at this time. We contend that the "Lutz-Terasaki fragment" is a genuine product of premissionary Rapa Nui. However, the "Lutz-Terasaki fragment" does not fit the definition, as set forth by S. R. Fischer and subsequently accepted by many researchers of rongorongo, of an inscription to be included in the primary canonical rongorongo corpus. As already noted, Fischer defines a rongorongo "inscription" as "a sequence of two or more glyphs that fulfil a communicatory function". 84

With only an isolated glyph, the "Lutz-Terasaki fragment" does not meet this requirement. Yet, we suggest that in the future, the "Lutz-Terasaki fragment" and its glyph should be included in an inventory and secondary

82 cf. TAYLOR, C. What is Corpus Linguistics? What the Data Says.

${ }^{83}$ Prior to the arrival of the missionary Joseph-Eugène Eyraud to the island in 1864; see footnote 9 , above.

${ }^{84}$ FISCHER, S. R. Rongorongo: The Easter Island Script, History, Traditions, Texts, p. ix; cf. also p. 155, footnote 82 in MELKA, T. S., SCHOCH, R. M. The Quest for Information Retrieval: An Inscribed Relic from Ancient Rapa Nui (Easter Island), Part I. A similar perspective (although concerning other non-identified scripts) is found in FERRARA, S., From Icon to Sign: Local Iconography and the Birth of the Cretan Hieroglyphic Script, p. 4 (citing GODART, L., OLIVIER, J-P., Recueil des Inscriptions en Linéaire A), "As convention dictates, an inscription is defined as the association of at least two, or more, consecutive signs arranged in a coherent sequence, with a consistent orientation (GORILA $\left.{ }^{3}\right)$ ". 
corpus or sub-corpus of pre-missionary artifacts bearing single rongorongo glyphs. Ultimately, we believe, the rongorongo corpus requires dispassionate and measured (i.e., deliberate, restrained, non-emotional, objective, and carefully considered) scholarly analyses if progress is to be made in rongorongo studies. Such analyses should address, among others, the artifact known as the "Lutz-Terasaki fragment" and its glyph.

- The suggested hypothesis, that the " $L-T$ fragment" once was an integral part of a handle of some sort of knife or other obsidian-pointed weapon, with the "bird"- / "human"-like glyph corresponding to warlike / ritualistic premises, seems to form specific connections with the current multi-layered data. In this sense, it is refreshing to survey Kononenko, Stevenson, et al. ${ }^{85}$; the authors, after analyzing the many potential uses of matā (= mata'a) from cave deposits (on the southern coast of Rapa Nui), hypothesize that

\section{"[...] the matā may have been initially devised for a specific task, but once the package of a strong edge, a precision grip, and a protective handhold was created, the tool form proliferated and was extended to many other activities. Eventually, creating a handle on obsidian tools became the cultural norm for many different tasks. Furthermore, the addition of a wooden handle might have become extended because it created a space that could be decorated and used for communicating cultural affiliation and/or ownership".}

Yet, as striking as the hypotheses of TSM and RMS and Kononenko, Stevenson, et al ${ }^{86}$ are, it does not necessarily follow that we have fully hit the bull's eye. It is acknowledged that other scenarios are possible, including the alternative hypotheses we have outlined previously, in the case of the " $L-T$ fragment". What is of importance, however, is a sound methodology in elucidating "puzzling" artifacts and records, as pursued by past and present scholars.

- Close consideration must also be given to the fact that the scribal activity was not tightly restrained to tablets and staves. Providing the hypothesis on the warlike / ceremonial-like use of the discussed fragment borders on the truth, it may offer further evidence on the social extent and use of script, as reported by

${ }^{85}$ KONONENKO, N., STEVENSON, C. M., et al. The Many Uses of matā on Rapa Nui, p. 88.

${ }^{86}$ Ibid. 
Joseph-Eugène Eyraud during his first visit in $1864 .{ }^{87}$ This line of investigation is likely to produce further results in recapturing the past of Rapa Nui (Easter Island).

- The present authors recognize that the rongorongo script is still nondeciphered (in the sense implied by M. Pope and M. Coe) ${ }^{88}$ However, depending on whom you listen to, syllabic and/or logographic values have been successfully assigned over various glyphs and passages, or complete tablet inscriptions have been translated. Given the characteristics of a "mysterious" phenomenon, rongorongo has the power to entice and attract the cautious, the self-confident, and the fanciful. As an "early script", ${ }^{89}$ on the other hand, it has the power to trigger more solutions than the sober-minded scholarship can handle. Attempts at full decipherment over the decades have fizzled out, and there is reason to suggest that many of them will not succeed in the future. However, it is not that we are prejudiced to accept (or not) the phonetic decipherment of rongorongo or want to undercut the related efforts in some way; we simply advise the international aspirants to keep check with each other and see if they come to an agreement regarding their submissions. ${ }^{90}$

${ }^{87}$ EYRAUD, J-E. Lettre du Frère Eugène Eyraud, au T. R. P. Supérieur Général de la Congrégation des Sacrés-Ceeurs de Jésus et de Marie. Valparaíso, décembre 1864.

${ }^{88}$ POPE, M. The Story of Decipherment: From Egyptian Hieroglyphs to Maya Script; COE, M. Phallus and Fallacy. Glyph-Breaker - Rongorongo; v. supra notes 3 and 4.

${ }^{89}$ The designation "early script" is out of convenience; essentially referring to a script as not fully "developed", rather than conceived and availed of at some "early" and "defective" stage along a timeline. Yet again, one has to consider the designation is potentially ambiguous since it may hint at some teleological classificatory scheme.

${ }_{90}$ While not agreed on all points, the identification of the so-called "Lunar Calendar" on the "Mamari Tablet" suggests otherwise a general consensus among the serious RR researchers. However, there is no full assurance on the exact "reading" of this textual passage. Commenting on such identification made by BARTHEL, T. S. Grundlagen zur Entzifferung der Osterinselschrift. (Abhandlungen aus dem Gebiet der Auslandskunde 64, Reihe B) on the "Mamari Tablet" (the "Lunar Calendar" text), FISCHER, S. R. Preliminary Evidence for Cosmogonic Texts in Rapanui's Rongorongo Inscriptions, $\mathrm{p}$. 304, says, "A phonetic statement of this brief "Mamari" passage has not been forthcoming in the intervening 39 years $[\rightarrow 63$ years to date; our note]"; see in addition, MELKA, T. S. in HARRIS, M., MELKA, T. S., The Rongorongo Script: On a Listed Sequence in the recto [verso; repaired] of Tablet 'Mamari', Part 1, p. 125, "An important achievement has been made nonetheless: the identification of a sequence of calendaric content describing a synodic month (see Barthel, 1958a, pp. 243-247; Guy, 1990), though so far there is no telling on how to read it conclusively". One has to imagine therefore the "phonetic readings" of rongorongo sequences / texts on which the scholarly consensus is more-than-negligible or inexistent. 
- Despite having occasional detective-like tones, the effects and hypotheses originating in this study may have an impact on other rongorongo artifacts possibly resurfacing in the future. ${ }^{91}$ Until that uplifting moment happens, discretion is in order.

\section{REFERENCES}

ARNHEIM, Rudolf. Art and Visual Perception: A Psychology of the Creative Eye. The New Version. Berkeley / Los Angeles / London: University of California Press, 1997 [1954].

ARREDONDO, Ana María. Symbolism in Rapanui Art. In FISCHER, Steven R. (ed.). Easter Island Studies: Contributions to the History of Rapanui in Memory of William T. Mulloy (Oxbow Monograph 32). Oxford: Oxbow Books, 1993. pp. 214-224.

BAHN, Paul, FLENLEY, John. Easter Island, Earth Island. London: Thames \& Hudson, 1992.

BAHN, Paul. The End of the Moai - Did they fall or were they pushed? In CAUWE, Nicolas, DE DAPPER, Morgan. (Guest eds.). International Conference Easter Island: Collapse or Transformation? A State of the Art, Brussels, 9 - 10 November 2012 (Financially supported by Fonds de la Recherche Scientifique). Bruxelles: The Royal Academy for Overseas Sciences / Royal Museums of Art and History / Belgian Science Policy Office, 2015, pp. 135-152 [online] [cit. 12 October 2020]. Available from http://www.kaowarsom.be/documents/PUBLICATIONS/EASTER\%20ISLA ND_COLLAPSE_TRANSFORMATION.pdf.

BALFOUR, Henry. Some Ethnological Suggestions in Regard to Easter Island, or Rapanui. In Folklore, 1917, Vol. 28, No. 4, pp. 356-381 [online] [cit. 2 October 2021]. Available from https://doi.org/10.1080/0015587X.1917. 9719007.

${ }^{91}$ cf. BATISTA CAMPBELL, R. La Herencia Musical de Rapanui: Etnomusicología de la Isla de Pascua [The Musical Legacy of Rapanui: Ethnomusicology of Easter Island], p. 379. No long time elapsed between the first draft of the "Lutz-Terasaki fragment" article and when R. M. Schoch succeeded in locating another pre-missionary artifact held in a private collection (a small Easter Island "engraving tool"), the wooden handle of which shows a single rongorongo glyph corresponding to BARTHEL \# /97a/ (see Figs. 12a and 12c, in the Section PLATES). Regarding another artifact bearing a rongorongo-like glyphic set that has been recently examined by the present authors see: SCHOCH, R. M., MELKA, T. S. A "Sacred Amulet from Easter Island -1885/6-": Analyzing Enigmatic Glyphic Characters in the Context of the rongorongo Script. 
The Quest for Information Retrieval - Part II

BARKER, Christine. Plant portraits: 432. BROUSSONETIA PAPYRIFERA, Moraceae. In Curtis's Botanical Magazine (Published on behalf of the Royal Botanic Gardens, Kew), 2002, Vol. 19, No. 1, pp. 8-18.

BARTHEL, Thomas S. Resultados Preliminares del Desciframiento de las Kohau-rongorongo de la Isla de Pascua [Preliminary Results of the Decipherment of Easter Island's Kohau-rongorongo]. In Runa, Archivo para las Ciencias del Hombre (Buenos Aires), 1956, Vol. 7, pp. 233-241.

BARTHEL, Thomas S. Grundlagen zur Entzifferung der Osterinselschrift. (Abhandlungen aus dem Gebiet der Auslandskunde 64, Reihe B). Hamburg: Cram, de Gruyter \& Co., 1958a.

BARTHEL, Thomas S. The "Talking Boards" of Easter Island. In Scientific American, 1958b, Vol. 198, pp. 61-68.

BARTHEL, Thomas S. Obsidianwaffen von der Osterinsel. In Jahrbuch des Museums für Völkerkunde zu Leipzig, 1958c, Band 17, pp. 14-21.

BARTHEL, Thomas S. Rezitationen von der Osterinsel. In Anthropos, 1960, Vol. 55, pp. 841-859.

BARTHEL, Thomas S. Rongorongo-Studien (Forschungen und Fortschritte bei der Weiteren Entzifferung der Osterinselschrift). In Anthropos (Published by Nomos Verlagsgesellschaft mbH), 1963, Vol. 58, Nos. 3-4, pp. 372-436 [online] [cit. 1 February 2020]. Available from https://www.jstor.org/stable/ 40455963.

BARTHEL, Thomas S. Pre-contact Writing in Oceania. In SEBEOK, Thomas Albert (ed.), DONALD BOWEN, J., DYEN, Isidore, GRACE, George W., WURM, Stephen A. (associate eds.), et al. Linguistics in Oceania: Current Trends in Linguistics. Part Two. Selected Topics. Vol. 8. The Hague, Paris: Mouton \& Co. N. V., Publishers, 1971. pp. 1165-1186.

BATISTA CAMPBELL, Ramón. La Herencia Musical de Rapanui: Etnomusicología de la Isla de Pascua [The Musical Legacy of Rapanui: Ethnomusicology of Easter Island]. Santiago de Chile: Editorial Andrés Bello, 1971.

BEARDSLEY, Felicia Rounds. Bone Tool Technology on Easter Island. In Rapa Nui Journal, 1996, Vol. 10, No. 4, pp. 77-80.

BELLWOOD, Peter. Man's Conquest of the Pacific: The Prehistory of Southeast Asia and Oceania. New York: Oxford University Press, 1979 [1978].

BEST, Elsdon. Notes on the Art of War, as Conducted by the Maori of New Zealand, with Accounts of Various Customs, Rites, Superstitions, \&c., Pertaining to War, as Practised and Believed in by the Ancient Maori. Part III. In The Journal of the Polynesian Society, 1902, Vol. 11, No. 43, pp. $127-162$.

BLIXEN, Olaf. Figuras de Hilo Tradicionales de la Isla de Pascua y sus Correspondientes Salmodias [Traditional String Figures from Easter Island 
and their Corresponding Recitations]. In Moana: Estudios de Antropología Oceánica (Montevideo), 1979, Vol. 2, No. 1, pp. 1-106.

BOLLT, Robert, CLARK, Jesse E., FISHER, Philip R., YOSHIDA, Hirosato K. An Experiment in the Replication and Classification of Easter Island mata 'a. In Rapa Nui Journal, 2006, Vol. 20, No. 2, pp. 125-133 [online] [cit. 2 February 2021]. Available from https://kahualike.manoa.hawaii.edu/cgi/ viewcontent.cgi? article $=1635 \&$ context $=$ rnj.

BÓRMIDA, Marcelo. Formas y Funciones del "Matá", el Más Conocido Artefacto de la Arqueología de Pascua [Shapes and Functions of "Matá", the Most Well-known Archaeological Artifact of Easter Island]. In Runa, Archivo para las Ciencias del Hombre (Buenos Aires), 1951, Vol. 4, No. 12, pp. 296-308.

BOWER, Bruce. Easter Islanders Made Tools, Not War. Artifacts Challenge Idea that Violence led to Rapa Nui Collapse. In Science News. Humans \& Society, 19 March, 2016, p. 11 [online] [cit. 17 March 2021]. Available from https://www.sciencenews.org/wp-content/uploads/2015/09/\%20Rapa Nui.pdf.

BROWN, John Macmillan. The Riddle of the Pacific (Reprint of the 1924 edition. Adelphi Terrace, London: T. Fisher Unwin Ltd.). Edition published in 1979, New York: AMS, 1979 [1924].

BUTINOV, Nikolai A., KNOROZOV, Yuri V. Preliminary Report on the Study of the Written Language of Easter Island. In Journal of the Polynesian Society, 1957 [1956], Vol. 66, No. 1, pp. 5-17.

CAUWE, Nicolas, DE DAPPER, Morgan. (Guest eds.). International Conference Easter Island: Collapse or Transformation? A State of the Art, Brussels, 9 \& 10 November 2012 (Financially supported by Fonds de la Recherche Scientifique). Bruxelles: The Royal Academy for Overseas Sciences / Royal Museums of Art and History / Belgian Science Policy Office, 2015 [online] [cit. 12 October 2020]. Available from http://www.kaowarsom.be/documents/PUBLICATIONS/EASTER\%20ISLA ND_COLLAPSE_TRANSFORMATION.pdf.

CHRISTMANN, Friedrich, OBERLÄNDER, Richard. Ozeanien, die Inseln der Südsee. Aeltere und neuere Erforschungsreisen im Gebiete der Inselgruppen des Stillen Ozeans. Mit besonderer Rücksicht auf Leben, Sprache und Sitten der aussterbenden Naturvölker jener Eilande. 2 Teile in einem Band, 1 Band. Leipzig: Otto Spamer Verlag, 1873.

CHURCHILL, William. The Rapanui Speech and the Peopling of Southeast Polynesia. Publication No. 174. Washington: The Carnegie Institution of Washington, 1912 [online] [cit. 10 May 2019]. Available from https:// archive.org/stream/easterislandrapa00churrich/easterislandrapa00churrich_dj vu.txt. 
COE, Michael. Phallus and Fallacy. Glyph-Breaker - Rongorongo. In Times Higher Education Supplement, 30 March 1998, pp. 24-25 [online] [cit. 12 April 2016]. Available from https://www.timeshighereducation.com/ books/phallus-and-fallacy/163001.article.

CONRICH, Ian, MÜCKLER, Hermann (eds.). Easter Island: Cultural and Historical Perspectives. Berlin: Frank \& Timme, 2016.

COOKE, George H. Te Pito te Henua, known as Rapa-Nui, commonly called Easter Island, South Pacific Ocean. In Annual Reports Smithsonian Institution for 1897. Washington D.C.: Smithsonian Institution, United States National Museum, 1899. pp. 689-723 [online] [cit. 28 November 2019]. Available from https://archive.org/details/tepitotehenuakno00cook/ page/n6.

DE VERE BAILEY, B. A. Notes on Oceanian War Clubs. In The Journal of the Polynesian Society, March 1947, Vol. 56, No. 1, pp. 3-17.

DEDEREN, François. Corpus Rapa Nui. Inventaire Mondial de la Statuaire en Bois de l'île de Pâques / Corpus Rapa Nui: Global Inventory of the Wooden Statuary of Easter Island. Braine-L'Alleud, Belgium: François Dederen / DCL Printers, 2013.

DEDEREN, François. Île de Pâques: L'Origine de l'Écriture rongorongo. In Les Articles en Ligne de Kadath (Brussels), Août 2019, pp. 5-14 [online] [cit. 3 October 2019]. Available from https://berphi.skyrock.com/973.html.

DiNAPOLI, Robert J., LIPO, Carl L., HUNT, Terry L. Revisiting Warfare, Monument Destruction, and the 'Huri Moai' Phase in Rapa Nui (Easter Island) Culture History. In Journal of Pacific Archaeology, 2020, Vol. 12, No. 1, pp. 1-24 [online] [cit. 19 May 2021]. Available from https://pacificarchaeology.org/index.php/journal/article/view/313.

DOMENY DE RIENZI, Gabriel Louis. Océanie, ou Cinquième Partie du Monde. Revue Géographique et Ethnographique de la Malaisie, de la Micronésie, de la Polynésie et de Mélanésie. Tome Deuxième. Paris: Firmin Didot Frères et $C^{\text {ie }}$, Éditeurs, 1843 [1836] [online] [cit. 6 May 2019]. Available from https://archive.org/details/ocanieoucinquie01riengoog/page/ n12.

DROGIN, Marc. Biblioclasm: The Mythical Origins, Magic Powers, and Perishability of the Written Word. Savage, Maryland: Rowman and Littlefield, 1989.

DU FEU, Veronica. Rapa Nui (Descriptive Grammars). London and New York: Routledge, 1996.

EDGE-PARTINGTON, James, HEAPE, Charles. An Album of the Weapons, Tools, Ornaments, Articles of Dress, \&c., of the Natives of the Pacific Islands, Vol. I, 12-14; Vol. II, 10. Manchester: Palmer, Howe \& Co., $1890-$ 1898. 
EDLER, John Charles. Art of Polynesia. Honolulu, Hawai'i: Hemmeter Publishing Corporation, 1990.

EDWARDS, Edmundo, EDWARDS, Alexandra. When the Universe was an Island: Exploring the Cultural and Spiritual Cosmos of Ancient Rapa Nui. Hangaroa, Easter Island: Hangaroa Press, 2013.

EMORY, Kenneth P. East Polynesian Relationships as Revealed through Adzes. In YAWATA, Ichirō, SINOTO, Yosihiko H. (eds.). Prehistoric Culture in Oceania. A Symposium of the 11th Pacific Science Congress, Tokyo, 1966. Honolulu: B. P. Bishop Museum Press, 1968. pp. 151-169.

ENGLERT, Sebastian. La Tierra de Hotu Matu'a: Historia, Etnología y Lengua de la Isla de Pascua. [The Land of Hotu Matu'a: History, Ethnology, and Language of Easter Island]. Santiago de Chile: Padre las Casas, 1948.

ENGLERT, Sebastian. Island at the Center of the World: New Light on Easter Island. New York: Charles Scribner's Sons, 1970.

EVANS, Jeff. Maori Weapons in Pre-European New Zealand. Honolulu: University of Hawai'i Press, 2014 [2002].

EYRAUD, Joseph-Eugène. Lettre du Frère Eugène Eyraud, au T. R. P. Supérieur Général de la Congrégation des Sacrés-Cœurs de Jésus et de Marie. Valparaíso, décembre 1864. In Annales de la Propagation de la FoiRecueil Périodique des Lettres des Evêques et des Missionnaires des Missions des Deux Mondes, et de tous les Documents Relatifs aux Missions et a l'Euvre de la Propagation de la Foi (Lyon, chez l'Éditeur des Annales), 1866, Vol. 38, pp. 52-71, 124-138.

FARAONE, Christopher A., OBBINK, Dirk (eds.). Magika Hiera: Ancient Greek Magic and Religion. New York / Oxford: Oxford University Press, 1997 [1991].

FERBER, Michael. A Dictionary of Literary Symbols. New York: Cambridge University Press, 1999.

FERRARA, Silvia. From Icon to Sign: Local Iconography and the Birth of the Cretan Hieroglyphic Script. In Terrain anthropologie \& sciences humaines, October 2018, No. 70, pp. 1-23 [online] [cit. 18 September 2020]. Available from http://doi.org/10.4000/terrain.17225.

FIGUEROA, Gonzalo, SÁNCHEZ, Eduardo. Adzes from Certain Islands of Eastern Polynesia. In HEYERDAHL, Thor, FERDON, JR., Edwin N. (eds.). Reports of the Norwegian Archaeological Expedition to Easter Island and the East Pacific. Vol. 2. Santa Fe: School of Research Museum, 1965. pp. 169-254.

FISCHER, Steven R. (ed.). Easter Island Studies: Contributions to the History of Rapanui in Memory of William T. Mulloy (Oxbow Monograph 32). Oxford: Oxbow Books, 1993. 
The Quest for Information Retrieval - Part II

FISCHER, Steven R. Preliminary Evidence for Cosmogonic Texts in Rapanui's Rongorongo Inscriptions. In The Journal of the Polynesian Society (Published quarterly by the Polynesian Society [Inc.], Auckland, New Zealand), September 1995, Vol. 104, No. 3, pp. 303-321.

FISCHER, Steven R. Rongorongo: The Easter Island Script, History, Traditions, Texts. Oxford: Oxford University Press, 1997.

FISCHER, Steven R. Island at the End of the World: The Turbulent History of Easter Island. London: Reaktion Books Ltd, 2005.

FLAS, Damien. The Mata'a and the "Collapse Hypothesis". In CAUWE, Nicolas, DE DAPPER, Morgan (Guest eds.). International Conference Easter Island: Collapse or Transformation? A State of the Art, Brussels, 9 \& 10 November 2012 (Financially supported by Fonds de la Recherche Scientifique). Bruxelles: The Royal Academy for Overseas Sciences / Royal Museums of Art and History / Belgian Science Policy Office, 2015, pp. 5975 [online] [cit. 12 October 2020]. Available from http://www.kaowarsom. be/documents/PUBLICATIONS/EASTER\%20ISLAND_COLLAPSE_TRA NSFORMATION.pdf.

FUENTES, Jordi. Diccionario y Gramática de la Lengua de la Isla de Pascua. Pascuense-Castellano, Castellano-Pascuense. Dictionary \& Grammar of the Easter Island Language. Pascuense-English, English-Pascuense. Santiago de Chile: Editorial Andrés Bello, 1960.

GARRETT, Paul. Making, Breaking Codes: An Introduction to Cryptology. Upper Saddle River, New Jersey: Prentice Hall, 2001.

GARROD, Simon, FAY, Nicolas, LEED, John, OBERLANDER, Jon, MACLEOD, Tracy. Foundations of Representation: Where Might Graphical Symbol Systems Come From? In Cognitive Science (Cognitive Science Society), 2007, Vol. 31, pp. 961-987 [online] [cit. 2 October 2021]. Available from https://doi.org/10.1080/03640210701703659.

GEISELER, Wilhelm (Kapitänlieutenant). Die Oster-Insel (Eine Stätte prähistorischer Kultur in der Sudsee). Geiseler's Easter Island Report: An 1880s Anthropological Account. With an Introduction, Annotations and Notes, by AYRES, William S. Translated by AYRES, William S., AYRES, Gabriella S. Asian and Pacific Archaeology series, No. 12. Honolulu: University of Hawai'i at Manoa, 1995 [1883].

GELB, Ignace J., WHITING, R. M. Methods of Decipherment. In The Journal of the Royal Asiatic Society of Great Britain and Ireland, 1975, No. 2, pp. 95-104 [online] [cit. 1 October 2021]. Available from https://www.jstor.org/ stable/25203647.

GODART, Louis, OLIVIER, Jean-Pierre. Recueil des Inscriptions en Linéaire $A$ [A Collection of the Linear A Inscriptions]. Etudes Crétoises, 21. Vols. 15. [GORILA]. Paris: Éditions P. Geuthner, 1976-1985. 
GILL, George W., OWSLEY, Douglas W. Human Osteology of Rapanui. In FISCHER, Steven Roger (ed.). Easter Island Studies: Contributions to the History of Rapanui in Memory of William T. Mulloy (Oxbow Monograph 32). Oxford, UK: Oxbow Monograph 32, 1993. pp. 56-62.

GOLSON, J. Thor Heyerdahl and the Prehistory of Easter Island. In Oceania, September 1965, Vol. 36, No. 1, pp. 38-83 [online] [cit. 17 July 2019]. Available from https://www.jstor.org/stable/40329509.

GUY, Jacques B. M. On the Lunar Calendar of Tablet 'Mamari.' In Journal de la Société des Océanistes (Paris), 1990, Vol. 91, No. 2, pp. 135-149.

GUY, Jacques B. M. Peut-on se Fonder sur le Témoignage de Métoro pour Déchiffrer les Rongo-Rongo? In Journal de la Société des Océanistes (Paris), 1999, Vol. 108, No. 1, pp. 125-132.

HARALAMBOUS, Yannis (ed.). Graphemics in the 21st Century. Brest, June 13 - 15, 2018. Proceedings Grapholinguistics and Its Applications, Vol. 1. Brest (France): Fluxus Editions, 2019.

HARRIS, Martyn, MELKA, Tomi S. The Rongorongo Script: On a Listed Sequence in the recto [verso; repaired] of Tablet 'Mamari', Part I. In Journal of Quantitative Linguistics, 2011a, Vol. 18, No. 2, pp. 122-173 [online] [cit. 2 October 2021]. Available from https://doi.org/10.1080/ 09296174.2011.556003.

HARRIS, Martyn, MELKA, Tomi S. The Rongorongo Script: On a Listed Sequence in the recto [verso; repaired] of Tablet 'Mamari', Part II. In Journal of Quantitative Linguistics, Part II, 2011b, Vol. 18, No. 3, pp. 234 273 [online] [cit. 2 October 2021]. Available from https://doi.org/10.1080/ 09296174.2011.581850.

HARRISON, James Park. The Hieroglyphics of Easter Island, With Plates xx and xxi. In The Journal of the Royal Anthropological Institute of Great Britain and Ireland, 1874, Vol. 3, pp. 370-384.

HEYERDAHL, Thor, FERDON, Edwin N. Jr. (eds.). Archaeology of Easter Island: Reports of the Norwegian Archaeological Expedition to Easter Island and East Pacific. Monographs of the School of American Research and the Museum of New Mexico. No. 24, Part 1, 1961. Stockholm: Forum Publishing House.

HEYERDAHL, Thor. An Introduction to Easter Island - History. In HEYERDAHL, Thor, FERDON Jr., Edwin N. (eds.). Miscellaneous Papers: Reports of the Norwegian Archaeological Expedition to Easter Island and East Pacific. Monographs of the School of American Research and the KonTiki Museum, No. 24, Part 1, 1961. Stockholm: Forum Publishing House. pp. 33-90.

HEYERDAHL, Thor. The Concept of RONGO-RONGO among the Historic Population of Easter Island. Report 16. In HEYERDAHL, Thor, FERDON 
Jr., Edwin N. (eds.). Miscellaneous Papers: Reports of the Norwegian Archaeological Expedition to Easter Island and East Pacific. Monographs of the School of American Research and the Kon-Tiki Museum, Number 24, Part 2, 1965. Stockholm: Forum Publishing House. pp. 345-385.

HEYERDAHL, Thor. The Art of Easter Island. Garden City, New York: Doubleday \& Company, Inc., 1975.

HICKS, Dan, HAMILTON, Sue, THOMAS, Mike Seager, WHITEHOUSE, Ruth. Easter Island and Pitcairn Island. In HICKS, Dan, STEVENSON, Alice (eds.). World Archaeology at the Pitt Rivers Museum: A Characterization. Oxford, England: Archaeopress, 2013. pp. 564-572.

HOOPER, Steven. Pacific Encounters: Art \& Divinity in Polynesia 1760 1860. (Published to accompany the Exhibition Pacific Encounters: Art \& Divinity in Polynesia $1760-1860$, Sainsbury Centre for Visual Arts, University of East Anglia, Norwich, 21 May - 13 August 2006). London: The British Museum Press, 2006.

HORLEY, Paul. Rongorongo Tablet Keiti. In Rapa Nui Journal, 2010, Vol. 24, No. 1, pp. 45-56.

IMBELLONI, José. Las 'Tabletas Parlantes' de Pascua, Monumentos de un Sistema Gráfico Indo-oceánico [The 'Talking Tablets' of Easter Island, Monuments of an Indo-Oceanic Graphic System]. In Runa, Archivo para las Ciencias del Hombre (Buenos Aires), 1951, Vol. 4, No. 1-2, pp. 89-177.

IVORY, Carol S. Marquesan 'U'u [= war clubs; our note]: A Stylistic and Historical Review. In Pacific Arts (The Journal of the Pacific Arts Association), July 1994, Vols. 9-10, pp. 53-63 [online] [cit. 15 March 2021]. Available from https://www.jstor.org/stable/23409886?refreqid= excelsior\%3A98b5d289787cf6517861c8668afd9c0e\&seq=1.

JARAMILLO, Álvaro, JOHNSON, Marc T. J., ROTHFELS, Carl J., JOHNSON, Ryan A. The Native and Exotic Avifauna of Easter Island: Then and Now. In Boletín Chileno de Ornitología, 2008, Vol. 14, No. 1, pp. 8-21.

JAUSSEN, Florentine É. [= Tepano]. L'Île de Pâques. Historique, Ecriture et Répertoire des Signes des Tablettes ou Bois d'hibiscus Intelligents (Published by Rev. P. Ildefonse Alazard). Paris: Ernest Leraux, 1893.

JENNINGS, Jesse D. (ed.). The Prehistory of Polynesia. Cambridge, MA / London, England: Harvard University Press, 1979.

KAEPPLER, Adrienne L. Sculptures of Barkcloth and Wood from Rapa Nui: Symbolic Continuities and Polynesian Affinities. In RES: Anthropology and Aesthetics, 2003, Vol. 44, pp. 10-69.

KAEPPLER, Adrienne L., VAN TILBURG, Jo Anne. The Iconic Tattooed Man of Easter Island. Melbourne, Victoria, Australia / Warren, CT: Mana Press / Floating World Editions, 2018. 
KAEPPLER, Adrienne L., VAN TILBURG, Jo Anne. Carved Komari (Vulva) Stones from Rapa Nui: Museum Objects, Legacy Data and Contemporary Local History. In The Journal of the Polynesian Society, 2020, Vol. 129, No. 4, pp. 383-406.

KAVANAGH, Christopher. Did Easter Island Culture Collapse? The Answer Is Not Simple. In AEON Newsletter, 2016 [online] [cit. 5 March 2021]. Available from https://aeon.co/ideas/the-easter-island-controversy-has-nosingle-simple-answer.

KJELLGREN, Eric (ed.). Splendid Isolation: Art of Easter Island. With contributions by Jo Anne Van Tilburg and Adrienne L. Kaeppler. New York: The Metropolitan Museum of Art / New Haven \& London: Yale University Press, 2001.

KJELLGREN, Eric. Oceania: Art of the Pacific Islands in the Metropolitan Museum of Art. O'NEILL, John P. (Publisher and Ed.-in-chief). New York: The Metropolitan Museum of Art / New Haven and London: Yale University Press, 2007.

KLEMMER, Konrad, ZIZKA, Georg. The Terrestrial Fauna of Easter Island. In FISCHER, Steven R. (ed.). Easter Island Studies: Contributions to the History of Rapanui in Memory of William T. Mulloy (Oxbow Monograph 32). Oxford: Oxbow Books, 1993. pp. 24-26.

KONONENKO, Nina, STEVENSON, Christopher M., WHITE, Peter, KELLOWAY, Sarah, TORRENCE, Robin. The Many Uses of matā on Rapa Nui. In Rapa Nui Journal (University of Hawai'i Press), 2019, Vol. 32, Nos. 1 \& 2, pp. 58-106 [online] [cit. 2 October 2021]. Available from https://doi.org/10.1353/rnj.2019.0001.

KRUPA, Viktor. The Symbol for Lizard in the Writing of Easter Island. In Asian and African Studies (Bratislava), 1974, Vol. 10, pp. 61-67.

LAURIÈRE, Christine. L'Odyssée Pascuane: Mission Métraux-Lavachery, Île de Pâques (1934 - 1935). Lahic / Ministère de la Culture et de la Communication, Direction Générale des Patrimoines, Département du Pilotage de la Recherche et de la Politique Scientifique. Charenton-Le-Pont: Encyclopédie en ligne Bérose, 2014 [online] [cit. 14 March 2021]. https://www.academia.edu/12377978/LOdyss\%C3\%A9e_pascuane_Mission _M\%C3\%A9traux_Lavachery_\%C3\%A0_IIle_de_P\%C3\%A2ques_1934_1 935_.

LAVACHERY, Thomas. Ile de Pâques 1934 - 1935: Expédition MétrauxLavachery. Bruxelles: Buch Edition, 1995.

LEE, Georgia. The Rock Art of Easter Island - Symbol of Power, Prayers to the Gods. Monumenta Archaeologica. Los Angeles, California: Coetsen Institute of Archaeology / University of California Press, 1992. 
LEE, Georgia. The Rock Art of Rapanui. In FISCHER, Steven Roger (ed.). Easter Island Studies: Contributions to the History of Rapanui in Memory of William T. Mulloy (Oxbow Monograph 32). Oxford, UK: Oxbow Books, 1993. pp. 112-121.

LEHMANN, Walter. Essai d'une Monographie Bibliographique sur l'Île de Pâques. Translated into French by R. P. Théophané CALMES (des Sacrés Cœurs de Picpus). In Anthropos (Salzburg), 1907, Vol. 2, pp. 141-151, 257268 [online] [cit. 14 January 2020]. Available from https://www.digihub.de/viewer/image/DE-11-001852164/223/LOG_0061/.

LELIÈVRE, Francine, POTHIER, L., CONCIATORI, C., POUSSART, Annick, MAJOR, Éric. Easter Island: An Epic Voyage. Montréal Museum of Archaeology and History. Montreal: Pointe-à-Callière, 2010.

LIPO, Carl P., HUNT, Terry L., HUNDTOFT, Brooke. Stylistic Variability of Stemmed Obsidian Tools (mata'a), Frequency Seriation, and the Scale of Social Interaction on Rapa Nui (Easter Island). In Journal of Archaeological Science, 2010, Vol. 37, No. 10, pp. 2551-2561.

LIPO, Carl P., HUNT, Terry L., HORNEMAN, Rene, BONHOMME, Vincent. Weapons of War? Rapa Nui mata'a Morphometric Analyses. In Antiquity, 2016, Vol. 90, No. 349, pp. 172-187 [online] [cit. 2 October 2021]. Available from https://doi.org/10.15184/aqy.2015.189.

MAIANI, Margherita, QUER, Soizic (eds.). Voyage vers l'Île Mystérieuse de la Polynésie a l'Ille de Pâques 20 Avril - 15 Septembre 1996. Musée d'Aquitaine, Bordeaux, Mairie de Bordeaux. Translation from the Italian by BARONE VISIGALLI, Egle, PUAUX, Olivier. Milan: Amilcare Pizzi Editore, 1996.

McCALL, Grant. European Impact on Easter Island: Response, Recruitment, and the Polynesian Experience in Peru. In The Journal of Pacific History, 1976, Vol. 11, No. 2, pp. 90-105 [online] [cit. 2 October 2021]. Available from https://www.jstor.org/stable/25168254?seq=1\#metadata_info_tab_ contents.

McCALL, Grant. Rapanui: Tradition and Survival on Easter Island. 2nd ed. Honolulu: University of Hawai‘i Press, 1994.

McCOY, Patrick Carleton. A Note on Easter Island, Obsidian Cores and Blades. In The Journal of the Polynesian Society, 1976, Vol. 85, No. 2, pp. 327-338.

McCOY, Patrick. Easter Island. In JENNINGS, Jesse D. (ed.). The Prehistory of Polynesia. Cambridge, MA / London, England: Harvard University Press, 1979. pp. 135-147.

McLUHAN, Marshall. Understanding Media: The Extensions of Man. New York: McGraw-Hill, 1964. 
MELKA, Tomi S. Some Considerations about the Kohau Rongorongo Script in the Light of a Statistical Analysis of the 'Santiago Staff'. In Cryptologia, 2009, Vol. 33, No. 1, pp. 24-73.

MELKA, Tomi S. On a "Kinetic"-like Sequence in rongorongo Tablet "Mamari". In Writing Systems Research, 2013, Vol. 5, Nos. 1-2, pp. 54-72 [online] [cit. 2 October 2021]. Available from https://dx.doi.org/10.1080/ 17586801.2012.742005.

MELKA, Tomi S. Distinctive Sequences in rongorongo Texts C, G, and B. In CONRICH, Ian, MÜCKLER, Hermann (eds.). Easter Island: Cultural and Historical Perspectives. Berlin: Frank \& Timme, 2016. pp. 217-236.

MELKA, Tomi S., ALTMANN, Gabriel. Script Complexity: A Case Study. In Glottometrics (RAM-Verlag), 2014, Vol. 28, pp. 56-74.

MELKA, Tomi S., SCHOCH, Robert M. Exploring a Mysterious Tablet from Easter Island: The Issues of Authenticity and Falsifiability in rongorongo Studies. In Cryptologia, 2020, Vol. 44, No. 6, pp. 481-544 [online] [cit. 2 October 2021]. Available from https://doi.org/10.1080/01611194.2019. 1706065.

MELKA, Tomi S., SCHOCH, Robert M. The Quest for Information Retrieval: An Inscribed Relic from Ancient Rapa Nui (Easter Island) - Part I. In Asian and African Studies (Bratislava), 2021, Vol. 30, No. 1, pp. 137-172, 249253 (Figures 1-6) [online] [cit. 1 June 2021]. Available from https://www.sav.sk/?lang=sk\&doc=journallist\&part=article_response_page \&journal_no=25984.

MÉTRAUX, Alfred. Two Easter Island Tablets in Bernice Pauahi Bishop Museum, Honolulu. With Plate A. In MAN, A Monthly Record of Anthropological Science (The Royal Anthropological Institute of Great Britain and Ireland, London), January 1938, Vol. 38, No. 1, pp. 1-5.

MÉTRAUX, Alfred. Ethnology of Easter Island. Bernice P. Bishop Museum Bulletin 160. Honolulu: Bernice P. Bishop Museum Press, 1940.

MILLS, Andy. Violent Encounters: Historical Notes on the Curatorial Representation of Polynesian Weapons. In Journal of Museum Ethnography (Published by Museum Ethnographers Group), 2009, Vol. 21, pp. 186-201. Special Issue: Encounters with Polynesia: Exhibiting the Past in the Present [online] [cit. 13 May 2021]. Available from http://www.jstor.org/stable/ 41505550.

MONTAGUE, Leopold A. D. (Lieut.-Col.) Weapons and Implements of Savage Races (Australasia, Oceania, and Africa), pp. 6-137. London: "The Bazaar, Exchange \& Mart" Office / Printed in Great Britain by Billing and Sons, Ltd., Guildford and Esher, 1921. 
OJEDA, Carlos Charlin. Geo-etimología de la ISLA de PASCUA [Geological Etymology of EASTER ISLAND]. Santiago de Chile: Instituto Geográfico Militar, 1947.

OLIVARES, Gabriela, PEÑA-AHUMADA, Bárbara, PEÑAILILLO, Johany, PAYACÁN, Claudia, MONCADA, Ximena, SALDARRIAGA-CÓRDOBA, Mónica, MATISOO-SMITH, Elizabeth, CHUNG, Kuo-Fang, SEELENFREUND, Daniela, SEELENFREUND, Andrea. Human Mediated Translocation of Pacific paper mulberry [Broussonetia papyrifera $(L$.) L'Hér. ex Vent. (Moraceae)]: Genetic Evidence of Dispersal Routes in Remote Oceania. In PLoS ONE, 2019, Vol. 14, No. 6, 24 pages. e0217107 [online] [cit. 2 October 2021]. Available from https://doi.org/10.1371/journal.pone. 0217107.

OWSLEY, Douglas W., BARCA, Kathryn G., SIMON, Vicki E., GILL, George W. Evidence for Injuries and Violent Death. In STEFAN, Vincent H., GILL, George W. (eds.). Skeletal Biology of the Ancient Rapanui (Easter Islanders). Cambridge, UK: Cambridge University Press, 2016. pp. 222252.

PATERSON, Richard K. Collecting "Tribal Art" - Sacred or Secular? In International Journal of Cultural Property, August 2014, Vol. 21, No. 3, pp. 305-318 (SPECIAL ISSUE: Thinking about Cultural Property: The Legal and Public Policy Legacies of John Henry Merryman) [online] [cit. 2 October 2021]. Available from https://doi.org/10.1017/S0940739114000150.

PEARCE, Susan M. (ed.). Interpreting Objects and Collections (Leicester Readers in Museum Studies). Routledge: London and New York, 2003 [1994].

PHILIPPI, Rodulfo A. La Isla de Pascua i sus Habitantes [Easter Island and its Inhabitants]. In Anales de la Universidad Santiago de Chile [Memorias Científicas i Literarias. Jeografía], 1873, Vol. 43, pp. 365-434 [online] [cit. 9 January 2021]. Available from https://libros.uchile.cl/538.

POLLOCK, Nancy J. Traditional Foods of Rapanui. In FISCHER, Steven Roger (ed.). Easter Island Studies: Contributions to the History of Rapanui in Memory of William T. Mulloy (Oxbow Monograph 32). Oxford, UK: Oxbow Monograph 32, 1993. pp. 153-157.

POPE, Maurice. The Story of Decipherment: From Egyptian Hieroglyphs to Maya Script. Rev. ed. London: Thames \& Hudson, 1999 [1975].

POZDNIAKOV, Konstantin. Les Bases du Déchiffrement de l'Écriture de l'Ile de Pâques. In Journal de la Société des Océanistes, 1996, Vol. 103, No. 2, pp. 289-303.

QUIBELL, James Edward. The Ramesseum and the Tomb of Ptahhetep. London: Egypt Exploration Fund, 1896. 
RAMÍREZ ALIAGA, José Miguel. Rapanui Mataa, A Simple Artifact with a Complex History. In VOGT, Burkhard, KUHLEM, Annette, MIETH, Andreas, BORK, Hans-Rudolf (eds.). Easter Island and the Pacific: Cultural and Environmental Dynamics, 2019 [2015]. Berlin: Rapa Nui Press / Deutsches Archäologisches Institut. pp. 367-381.

RAVI, Sujith, KNIGHT, Kevin. Attacking Decipherment Problems Optimally with Low-Order N-gram Models. In Proceedings of the 2008 Conference on Empirical Methods in Natural Language Processing, Honolulu, October 2008, pp. 812-819, Association for Computational Linguistics [online] [cit. 18 September 2019]. Available from https://aclanthology.org/D08-1085.pdf.

REHBEIN, Malte, SAHLE, Patrick, SCHASSAN, Torsten (Eds.), in collaboration with ASSMANN, Bernhard, FISCHER, Franz, FRITZE, Christiane. Kodikologie und Paläographie im digitalen Zeitalter Codicology and Palaeography in the Digital Age. Schriften des Instituts für Dokumentologie und Editorik - Band 2. Norderstedt: Books on Demand $\mathrm{GmbH}, 2009$.

RICHARDS, Rhys. Easter Island 1793 to 1861: Observations by Early Visitors before the Slave Raids. Los Osos, California: Easter Island Foundation, 2008.

ROBB, John E. The Archaeology of Symbols. In Annual Review of Anthropology, 1998, Vol. 27, pp. 329-346 [online] [cit. 30 September 2021]. Available from https://doi.org/10.1146/annurev.anthro.27.1.329.

ROBINSON, Andrew. Lost Languages: The Enigma of the World's Undeciphered Scripts. New York: A Peter N. Nevraumont Book, published by arrangement with McGraw-Hill, 2002.

ROPITEAU, André. Une Visite au Musée Missionnaire des Pères des SacrésCœurs de Picpus à Braine-le-Comte (Belgique). In Bulletin de la Société des études océaniennes (Tahiti), 1936 [1935], Vol. 55, pp. 518-527 [online] [cit. 27 April 2021]. Available from https://evols.library.manoa.hawaii.edu/ handle/10524/46324.

ROUTLEDGE, Katherine (Mrs. SCORESBY ROUTLEDGE). The Mystery of Easter Island. The Story of an Expedition. London and Aylesbury: Hazell, Watson and Viney, LD., 1919.

SANKOFF, David, KRUSKAL, Joseph. Time Warps, String Edits, and Macromolecules: The Theory and Practice of Sequence Comparison. The David Hume series, Philosophy and Cognitive Science Reissues. Stanford, CA: CSLI Publications, 1999.

SCHÁVELZON, Daniel. From Ethnographical Subjects to Archaeological Objects: Pierre Loti on Easter Island (Rapa Nui). In Bulletin of the History of Archaeology, 2014, Vol. 24, No. 19, pp. 1-8 [online] [cit. 2 October 2021]. Available from http://dx.doi.org/10.5334/bha.2419. 
SCHOCH, Robert M., MELKA, Tomi S. The Rayitoki (Rangitoki) Bark-Cloth Piece: A Newly Recognized Rongorongo Fragment from Easter Island. In Asian and African Studies (Bratislava), 2019, Vol. 28, No. 2, pp. 113-148, 413-417 (Figures 1-7) [online] [cit. 2 October 2021]. Available from https://www.sav.sk/?lang=sk\&doc=journal-list\&part=article_response_page \&journalarticle_no $=17609$.

SCHOCH, Robert M., MELKA, Tomi S. The Rayitoki (Rangitoki) Fragment: Further Analysis of a Short Rongorongo Sequence on Bark-Cloth from Easter Island. In Asian and African Studies (Bratislava), 2020, Vol. 29, No. 1, pp. 26-41, 113-118 (Figures 1-9) [online] [cit. 2 October 2021]. Available from https://www.sav.sk/?lang=sk\&doc=journal-list\&part=article _response_page\&journal_article_no $=18453$.

SCHOCH, Robert M., MELKA, Tomi S. A "Sacred Amulet from Easter Island -1885/6-": Analyzing Enigmatic Glyphic Characters in the Context of the rongorongo Script. In HARALAMBOUS, Y. (ed.). Grapholinguistics in the 21st Century 2020. Proceedings, Grapholinguistics and Its Applications. Brest, France: Fluxus Editions, Part II, Vol. 5, 2021. pp. 847-903 [online] [cit. 2 October 2021]. Available from http://www.fluxus-editions.fr/gla5scho.pdf. (Paper based on a conference poster session presented on 17 June 2020 [online] [cit. 9 January 2021]. Available from http://www.fluxuseditions.fr/grafematik2020-files/schoch-slides.pdf.

SCHOTT, Sigfried. Symbol und Zauber als Grundform altägyptischen Denkens [Symbol and Magic as Basics in the Ancient Egyptian Thought]. In Studium Générale (Berlin / Göttingen / Heidelberg: Springer-Verlag), 1953, Vol. 6, No. 5, pp. 278-288.

SELIGMAN, Charles Gabriel. Note on an Obsidian Axe or Adze Blade from Papua. With Plate M. In MAN (The Journal of the Royal Anthropological Institute of Great Britain and Ireland, London), 1915, Vol. 15, Nos. 91-92, pp. 161-163.

SIMPSON Jr., Dale F. Captain A. W. F. Fuller's Contribution to The Field Museum's Easter Island Collection. In Rapa Nui Journal, 2010, Vol. 24, No. 1, pp. 20-28.

SHANNON, Claude E. Communication Theory of Secrecy Systems. In Bell System Technical Journal, 1949, Vol. 28, pp. 656-715 [online] [cit. 18 September 2019]. Available from http://pages.cs.wisc.edu/ rist/642-spring2014/shannon-secrecy.pdf.

SKINNER, Henry Devenish. On the patu Family and its Occurrence beyond New Zealand. In The Journal of the Polynesian Society, 1931, Vol. 40, No. 160, pp. 183-196.

SKOTTSBERG, Carl. Part I. Notes on a Visit to Easter Island. In SKOTTSBERG, Carl (ed.). The Natural History of Juan Fernandez and 
Easter Island. Vol. I, Geography, Geology, Origin of Island Life. Uppsala: Almqvist \& Wiksells Boktryckeri AB, 1920. pp. 3-20, Plates 1-14.

SMITHSONIAN INSTITUTION. Hafted adze (toki). In National Museum of Natural History - Anthropology Department, Washington D.C. USA, 2018. USNM: E129733-0 [online] [cit. 11 December 2019]. Available from https://collections.si.edu/search/detail/edanmdm:nmnhanthropology_833614 3 ? $\mathrm{q}=\% 22$ U.S.S.+Mohican $\% 22 \&$ record $=51 \&$ hlterm $=\% 26$ quot $\% 3$ BU.S.S. $\% 2$ B\%20Mohican\%26\%20quot $\% 3 \mathrm{~B} \&$ inline $=$ true.

SPECHT, Friedrich August Karl von (General-lieutenant). Geschichte der Waffen: Nachgewiesen und Erlautert durch die Kulturentwickelung der Völker und Beschreibung ihrer Waffen aus allen Zeiten. Cassel: Verlag von Carl Luckhardt, 1869 [online] [cit. 25 February 2020]. Available from https://reader.digitale-sammlungen.de//de/fs1/object/display/bsb10997339_ 00005.html.

STEFAN, Vincent H., GILL, George W. (eds.). Skeletal Biology of the Ancient Rapanui (Easter Islanders). Cambridge, UK: Cambridge University Press, 2016.

STEVENSON, Christopher M., SHAW, Leslie C., CRISTINO, Claudio. Obsidian Procurement and Consumption on Easter Island. In Archaeology in Oceania, 1984, Vol. 19, pp. 120-124 [online] [cit. 17 July 2019]. Available from https://www.jstor.org/stable/40386671.

STEVENSON, Christopher M., WOZNIAK, Joan, HAOA, Sonia. Prehistoric Agricultural Production on Rapanui. In Antiquity, December 1999, Volume 73, No. 282, pp. 801-812 [online] [cit. 1 October 2021]. Available from https://doi.org/10.1017/S0003598X00065546.

STOKES, Peter A. Computer-Aided Palaeography, Present and Future. In REHBEIN, Malte, SAHLE, Patrick, SCHASSAN, Torsten (eds.). in collaboration with ASSMANN, Bernhard, FISCHER, Franz, FRITZE, Christiane. Kodikologie und Paläographie im digitalen Zeitalter Codicology and Palaeography in the Digital Age. Schriften des Instituts für Dokumentologie und Editorik - Band 2. Norderstedt: Books on Demand GmbH, 2009. pp. 309-338.

STRUBBE, Johan H. M. Cursed Be He that Moves My Bones. In FARAONE, Christopher A., OBBINK, Dirk (eds.). Magika Hiera: Ancient Greek Magic and Religion. New York / Oxford: Oxford University Press, 1997 [1991]. pp. 33-60.

TAMARIZ, Mónica, ROBERTS, Seán G., ISIDRO MARTÍNEZ, J., SANTIAGO, Julio. The Interactive Origin of Iconicity. In Cognitive Science - A Multidisciplinary Journal, 2017, pp. 1-16 [online] [cit. 2 October 2021]. Available from https://doi.org/10.1111/cogs.12497. 
TAMBIAH, Stanley Jeyaraja. The Magical Power of Words. In MAN (The Journal of the Royal Anthropological Institute of Great Britain and Ireland, London), 1968, Vol. 3, No. 2, pp. 175-208.

TAYLOR, Charlotte. What is Corpus Linguistics? What the Data Says. In ICAME Journal, 2008, Vol. 32, pp. 179-200.

TILLEY, Christopher. Interpreting Material Culture. In PEARCE, Susan M. (ed.). Interpreting Objects and Collections (Leicester Readers in Museum Studies). Routledge: London and New York, 2003 [1994]. pp. 67-75.

THOMSON, William Judah. Te Pito te Henua, or Easter Island. Report of the United States National Museum for the Year Ending June 30, 1889. (Annual Reports of the Smithsonian Institution for 1889). Washington: Smithsonian Institution, 1891. pp. 447-552.

VALÉRIO, Miguel, FERRARA, Silvia. Rebus and Acrophony in Invented Writing. In Writing Systems Research, 2019, Vol. 11. No. 1, pp. 66-93 [online] [cit. 2 October 2021]. Available from https://doi.org/10.1080/1758 6801.2020.1724239.

VAN HOOREBEECK, Albert. La Vérité sur l'ile de Pâques. Le Havre: Pierrette d'Antoine éditeur, 1979.

VON DEN STEINEN, Karl. Die Marquesaner und Ihrer Kunst. Vol II. Berlin: Dietrich Reimer, 1928.

VON KOTZEBUE, Otto. Entdeckungsreise in die Südsee und nach der Berings-Straße zur Erforschung einer nordöstlichen Durchfahrt: unternommen in den Jahren 1815, 1816, 1817 und 1818 auf Kosten Sr. Erlaucht des Herrn Reichskanzlers Grafen Rumanzoff auf dem Schiffe Rurick unter dem Befehle des Lieutenants der russisch- kaiserlichen Marine. Wien: Kaulfuß und Krammer, 1825 [1821] [online] [cit. 13 April 2019]. Available from https://reader.digitale-sammlungen.de/de/fs1/object/display/bsb104659 51_00001.html.

WATELIN, Louis-Charles. Note sur l'Ecriture de l'Ile de Pâques. In Bulletin de la Société des Americanistes de Belgique, 1934, Vol. 13, pp. 63-66.

WIECZOREK, Rafał M. The Double-body Glyphs and Palaeographic Chronology in the rongorongo Script. In Rapa Nui Journal, 2011, Vol. 25, No. 2, pp. 31-40.

WIECZOREK, Rafał M. Putative Duplication Glyph in the rongorongo Script. In Cryptologia, 2017, Vol. 41, No. 1, pp. 55-72 [online] [cit. 2 October 2021]. Available from https://doi.org/10.1080/01611194.2016.1196052.

WIKIMEDIA.org. Photograph of the sooty tern Courtesy of Duncan Wright, U.S. Fish and Wildlife Service, 2019a [online] [cit. 19 November 2019]. Available from https://commons.wikimedia.org/wiki/File:Sterna_fuscata. JPG. 
WIKIMEDIA.org. Photograph of the frigate bird Courtesy of Clark Anderson / Aquaimages, 2019b [online] [cit. 19 November 2019]. Available from https://commons.wikimedia.org/wiki/File:Male_Frigate_bird.jpg.

WILLIAMS, Rev. Thomas. Fiji and the Fijians: The Islands and their Inhabitants. ROWE, George Stringer (ed.). Volume 1. London: Alexander Heylin, 1858 [online] [cit. 15 March 2021]. Available from https://archive.org/details/fijiandfijiansi00rowegoog/page/n4/mode/2up.

WORTH, Sol, GROSS, Larry. Symbolic Strategies. In Journal of Communications, 1974, Vol. 24, No. 4, pp. 27-39 [online] [cit. 1 October 2021]. Available from https://doi.org/10.1111/j.1460-2466.1974.tb00405.x.

YAWATA, Ichirō, SINOTO, Yosihiko H. (eds.). Prehistoric Culture in Oceania. A Symposium of the 11th Pacific Science Congress, Tokyo, 1966. Honolulu: B. P. Bishop Museum Press, 1968.

ZIZKA, Georg. Naturgeschichte der Osterinsel. In 1500 Jahre Kultur der Osterinsel: Schätze aus dem Land des Hotu Matua. Exhibition Catalogue of the Deutsch-Ibero-Amerikanische Gesellschaft, Frankfurt am Main, and the Senckebergische Naturforschende Gesellschaft, Frankfurt am Main. 5 April - 3 September 1989, Senckenberg Museum. Mainz am Rhein: Verlag Philipp von Zabern, 1989. pp. 21-38. 
The Quest for Information Retrieval - Part II

\section{Appendix}

Designations and descriptions of a number of rongorongo glyphs according to various researchers are not without their wit or pitfalls. Admittedly, a small number of them may not be irrevocably detached from the real-world referent; on the other hand, other ones seem to go in different directions. As long as we rely on visual descriptions, sober modern scholarship understands them as conventions, and not as individual translations of cultural or natural entities of ancient Rapa Nui.

Six instances, among the many, are worthwhile to explore:

(a) J. P. Harrison describes (humorously; we think) the leading glyph /380/ in the compound /380.1.3/ 勻雅 as “[...] a prognathous [= having a projecting lower jaw; our note] or dog-faced man"; 92 T. S. Barthel, in turn, does not indulge much in fantasies regarding compound /380.1/, "Die bildhafte Wiedergabe eines Rongorongo Mannes mit seinem hölzernen Stab..." [The picture repeatedly renders a (seated; our note) rongorongo man (rongorongo chanter with head in profile; our note) with its wooden staff (...)]. ${ }^{93}$ T. Heyerdahl, although less animatedly descriptive than J. P. Harrison, is still inclined toward "the [...] common bow-backed mammal with the gaping mouth [...]".94

Next, (b) in "Répertoire des Signes Idéographiques "Boustrophédon" de l'Ile de Pâques" [Inventory of Ideographic Signs "Boustrophedon" from Easter Island], subsection "Terre" [earth, land], of Monseigneur "Tepano" Jaussen, 95 the reading (= description) of Metoro concerning glyph /53/ and variants \|\|\|\| $\left.\int \&\right\} \|\{\|$ is ' $U a$, in French Pluie (= rain). In the article of R. M. Wieczorek, glyph /53/ corresponds descriptively to "[...] vertical waves that can point either right or left $[\ldots]$ ". ${ }^{96}$ Conversely, to borrow T. S. Melka and R. M. Schoch's

${ }^{92}$ HARRISON, J. P. The Hieroglyphics of Easter Island, With Plates xx and xxi, p. 377.

${ }^{93}$ BARTHEL, T. S. Grundlagen zur Entzifferung der Osterinselschrift, p. 309.

${ }^{94}$ HEYERDAHL, T. The Concept of RONGO-RONGO among the Historic Population of Easter Island. Report 16, p. 372.

95 JAUSSEN, F. É. L'Île de Pâques. Historique, Écriture et Répertoire des Signes des Tablettes ou Bois d'hibiscus Intelligents, p. 23; cf. FISCHER, S. R. Rongorongo: The Easter Island Script, History, Traditions, Texts, Chapter 9, Bishop Jaussen and Metoro Tau'a Ure.

${ }^{96}$ WIECZOREK, R. M. The Double-body Glyphs and Palaeographic Chronology in the rongorongo Script, p. 37. 
depiction of the same glyph: "In iconic terms, \# /53/ is reminiscent of hanging garlands rippled by the wind" ${ }^{97}$ By the very nature of its design (= glyph /53/), any of the three listed descriptions may come to the point; this still leaves the question of which is the most credible one? Until an incontrovertible and coherent decipherment of the rongorongo inscriptions is offered, we tend to believe these graphic "explanations" will remain notional at best.

(c) In order to further evaluate authorial descriptions, we cite J. B. M. Guy, who estimates visually glyph 等 (on $\mathrm{C} a 6[=\mathrm{Cr} 6]$ ) in the following terms, “[ [...] glyph V30a does look a bit like a loop of string frayed at both ends $[\ldots] "{ }^{98} \mathrm{P}$. Horley, in turn, does not show any substantial deviation in this regard, deeming glyph /30/ as a "double "feather garland". ${ }^{99}$ At this stage we have to take the shape of $/ \mathrm{V} 30 \mathrm{a} /$ as a simply observable phenomenon, and not as an expression of personal judgments.

(d) In the fourth case, T. S. Melka chooses to describe the combination of a "glyph 051" suffixed to a /76/-sign 0 023 as " "komari" (= female genitalia)", 100 whereas R. M. Wieczorek offers the "descriptive nickname" "pencil" for glyph "050 ". ${ }^{101}$ On the "Rayitoki (Rangitoki) bark-cloth fragment" glyph /50/

or $/ 50 \mathrm{f} / \mathrm{E}^{*}$ (if a few little thread-like filaments are regarded; although they may be simply the result of the reddish pigment "bleeding" into the bark-cloth) is similarly described as komari (vulva / vulvae) in Schoch and Melka. ${ }^{102}$ T. S.

${ }^{97}$ MELKA, T. S., SCHOCH, R. M. Exploring a Mysterious Tablet from Easter Island: The Issues of Authenticity and Falsifiability in rongorongo Studies, p. 529; BARTHEL, T. S. Rongorongo-Studien (Forschungen und Fortschritte bei der Weiteren Entzifferung der Osterinselschrift), p. 431, in line with Metoro's chants, settles on ‘'ua〉 [Regen = rain] for glyph $/ 53 /$ o

${ }^{98}$ GUY, J. B. M. The Lunar Calendar of Tablet 'Mamari', p. 142.

${ }^{99}$ HORLEY, P. Rongorongo Tablet Keiti, p. 54.

100 MELKA, T. S. Some Considerations about the Kohau Rongorongo Script in the Light of a Statistical Analysis of the 'Santiago Staff', p. 55, p. 56, Figure 16.

101 WIECZOREK, R. M. Putative Duplication Glyph in the rongorongo Script, p. 58, Figure 2, section B.

102 SCHOCH, R. M., MELKA, T. S. The Rayitoki (Rangitoki) Bark-Cloth Piece: A Newly Recognized Rongorongo Fragment from Easter Island, p. 132. (For further discussion of the Rayitoki Piece, see: SCHOCH, R. M., MELKA T. S. The Rayitoki (Rangitoki) Fragment: Further Analysis of a Short Rongorongo Sequence on BarkCloth from Easter Island.) 
Barthel relates "komari" (= vulva) to glyph /23/ 0 , but glyph /50/ features under the metaphorical label "henua" (= land, earth). ${ }^{103}$ The original source of the association of glyph /50/ with "Henua" [Terre in French] based on Metoro's chants is found in "Tepano" Jaussen's Île de Pâques... book. ${ }^{104}$ Another instance concerning the "sign of the vulva"105 and its alleged meaning "legitimate marriage" (= "marital union") is given in Geiseler $(1883, p$. 27; quoted in A. Métraux). ${ }^{106}$ It must be borne in mind that glyphs /50/, /50f/, and /51/ are interchangeable scribal variants, and with this point made, it should be cautioned that the cited descriptions qualify as individual conceptions and not as phonetic readings / translations (at least, on the part of R. M. Wieczorek; R. M. Schoch and T. S. Melka).

(e) Another occasion for grasping "differences" in depicting rongorongo "symbols" is the commentary of the commanding officer of the gunboat Hyäne, W. Geiseler, regarding the glyphic compound

103 BARTHEL, T. S. Rongorongo-Studien (Forschungen und Fortschritte bei der Weiteren Entzifferung der Osterinselschrift), pp. 430-431; see also CHURCHILL, W. The Rapanui Speech and the Peopling of Southeast Polynesia, p. 202, "henua land, country, region (heenua). henua tumu, native land", and FUENTES, J. Diccionario y Gramática de la Lengua de la Isla de Pascua. Pascuense-Castellano, CastellanoPascuense. Dictionary \& Grammar of the Easter Island Language. Pascuense-English, English-Pascuense, p. 736, "Henúa n. country, fatherland, territory / earth, world / field, ground, soil / placenta // [...]". Given that human females are a sexually reproducing species, in terms of "komari" glyph /50/ and its cited connotations, "menses" or a "menstruating woman" could well be in the realm of possibilities. Incidentally, the "Rayitoki (Rangitoki) bark-cloth fragment", on which glyph $/ 50 /$ is painted in reddish pigment, belonged to a young local woman (presumably a fertile one).

${ }^{104}$ JAUSSEN, F. É. L'Île de Pâques. Historique, Écriture et Répertoire des Signes des Tablettes ou Bois d'hibiscus Intelligents, p. 22.

105 After the bas-relief carvings found at the 'Orongo ceremonial precinct and other incised stone-surfaces found elsewhere; for specific instances, see HEYERDAHL, T. The Art of Easter Island, Plate 178e, stone pillow decorated with vulva symbols; VAN HOOREBEECK, A. La Vérité sur l'ile de Pâques, Plate IX, top; KJELLGREN, E. Splendid Isolation: Art of Easter Island, p. 18; KAEPPLER, A. L., VAN TILBURG, J. A., Carved Komari (Vulva) Stones from Rapa Nui: Museum Objects, Legacy Data and Contemporary Local History, p. 385, Figure 1a and 1b; p. 386, Figure 2a and 2b.

106 See MÉTRAUX, A. Ethnology of Easter Island, p. 400, in reference to GEISELER, W. (Kapitänlieutenant) Die Öster-Insel (Eine Stätte prähistorischer Kultur in der Sudsee); cf. also Geiseler's Easter Island Report: An 1880s Anthropological Account, p. 58, note 99, in the translation of AYRES, W. S., AYRES, G. S. 


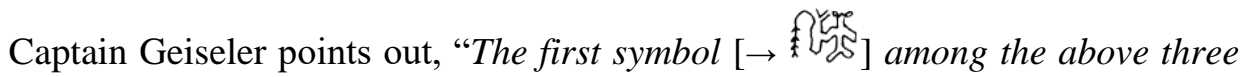
represents without a doubt a person with the seaweed he fished out, since this has precisely the same shape in nature as in the symbol, and therefore this symbol must indicate the season for collecting and consuming seaweed. During our stay this species of seaweed could be found only in the Hanga Piko and Hanga Roa bays and indeed they were very abundant in these locations [...]". ${ }^{107}$

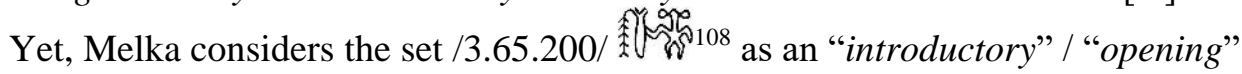
compound (or a "thematic index") along several passages found on Bv5-Bv7(8), ${ }^{109}$ reluctant to engage in descriptions. If we indulge for a moment, a fitting one would be that on "an anthropomorphic figure [= glyph /200/] holding a fish-like figure $[/ 65 /(=/ 700 \mathrm{x} /)$; head of the fish pointing down and tail in the air] embellished with a single feather garland $[=/ 3 /]$ ". The present readers should remember the ancient RR scribes / chanters did not encode modern English in their inscriptions nor did they "read" the glyphic set fashion of the earlier "description(s)".

(f) Finally, here we mention various "U-shaped" glyphs that may or may not be confused with one another or may possibly be variants of the same general class of glyphs. On the "Rayitoki (Rangitoki) fragment" there is a somewhat

enigmatic glyph that Schoch and Melka ${ }^{110}$ tentatively identified as glyph 近

17/ CS painted in a horizontal orientation. Glyph $/ 7 /$, often regarded in the literature as representing a rei miro (a type of indigenous wooden breastplate or gorget; see Fischer ${ }^{111}$ who asserted that /7/ depicts a rei miro), is not uncommon in the rongorongo corpus. An alternative interpretation of this Rangitoki glyph, considered but ultimately dismissed by Schoch and Melka, ${ }^{12}$ is the possibility

107 GEISELER, W. Geiseler's Easter Island Report: An 1880s Anthropological Account, p. 58.

108 The manual tracing of compound /3.65.200/ $(\rightarrow \mathrm{B} v 6)$ is after BARTHEL'S, T. S. Grundlagen zur Entzifferung der Osterinselschrift (Abhandlungen aus dem Gebiet der Auslandskunde 64, Reihe B).

${ }^{109}$ MELKA, T. S. Distinctive Sequences in rongorongo Texts C, G, and B, pp. 229-230.

${ }^{110}$ SCHOCH, R. M., MELKA, T. S. The Ranitoki (Rangitoki) Bark-Cloth Piece: A Newly Recognized Rongorongo Fragment from Easter Island, pp. 137-138.

${ }^{111}$ FISCHER, S. R. Rongorongo: The Easter Island Script, History, Traditions, Texts, p. 373.

112 SCHOCH, R. M., MELKA, T. S. The Rayitoki (Rangitoki) Bark-Cloth Piece: A Newly Recognized Rongorongo Fragment from Easter Island, pp. 137-139. 
that it might represent the extremely rare glyph /127a/ $\mathcal{L}$. In a follow-up article, Schoch and Melka ${ }^{113}$ explored the possibility that this particular Rangitoki glyph might represent an "upturned" version of glyph $/ 26 / 00$, namely $/ 26 \mathrm{x} / \mathrm{O}$. Furthermore, as Schoch and Melka noted, ${ }^{114} / 26 /$ may be a variant of the "horseshoe"-shaped glyph /27/ (Ueferencing /27/ as a "horseshoe" glyph is purely the application of a nickname for convenience, as the successful introduction of horses on Easter Island dates to the second half of the nineteenth century (Klemmer and Zizka, ${ }^{115}$ in Fischer, editor, Easter Island Studies; small horses are today found in abundance on Rapa Nui). In "Tepano" Jaussen's Île de Pâues... book, such a sign was identified by Metoro as haga (= haya) in Rapanui and baie in French [bay in English]. ${ }^{116}$ Synthesizing these observations, one might suggest that glyphs $/ 7 /, / 26 /, / 26 \mathrm{x} /, / 27 /$, and the Rangitoki glyph form a "family" of visually related glyphs. ${ }^{117}$

And to finish, given the iconic- / pictorial-like profile of many rongorongo signs, the reality of descriptions / nicknames cannot simply be dismissed or wished away. In our opinion, such descriptions / nicknames seem to be "unavoidable companions" as, so far, it appears we have few clues as to what each glyph stands precisely for in a single and/or multiple context(s) in semantic or phonetic terms, in tandem with the lack of an unambiguous and completely reliable index catalog of the rongorongo glyphs (Barthel's

113 SCHOCH, R. M., MELKA T. S. The Ranitoki (Rangitoki) Fragment: Further Analysis of a Short Rongorongo Sequence on Bark-Cloth from Easter Island, pp. 29-30. ${ }^{114}$ Ibid., p. 29.

115 KLEMMER, K., ZIZKA, G. The Terrestrial Fauna of Easter Island, p. 25.

116 JAUSSEN, F. É. L'Île de Pâques. Historique, Écriture et Répertoire des Signes des Tablettes ou Bois d'hibiscus Intelligents.

117 A coding error in Fig. 5 of MELKA, T. S., SCHOCH, R. M., The Quest for Information Retrieval: An Inscribed Relic from Ancient Rapa Nui (Easter Island) - Part $I$, was noticed too late to be corrected prior to publication. In the bottom left quadrant of the figure the code-number for the first compounded glyph $\mathrm{L}_{\mathrm{s}}$ (section Ta7) was given as $/ 7.76 /$ rather than $/ 27.76 /$ - yet, based on the reasoning presented here, this inadvertent error may suggest two visually related glyphs. A note at this juncture: however, we are not claiming that glyph $/ 7 /$ 领 is functionally (= contextually) of the same class with the series $/ 26 /, / 26 \mathrm{x} /, / 27 /$. Also, in the upper right quadrant of the same figure (section I $a 7$ ) the "bird"-like glyph /64s:664V/ should be re-coded as /64s:V664/ त्रित्री. 
remarkable work notwithstanding). ${ }^{118}$ However, such nicknames can lead to confusion and disagreements if or when they begin to be regarded as more than mere nicknames of convenience, a problem plaguing other non-deciphered systems as well; see e.g., Robinson; cf. Melka and Schoch. ${ }^{119}$

${ }^{118}$ BARTHEL, T. S. Grundlagen zur Entzifferung der Osterinselschrift (Abhandlungen aus dem Gebiet der Auslandskunde 64, Reihe B).

119 See specifically ROBINSON, A. Lost Languages: The Enigma of the World's Undeciphered Scripts, p. 295, regarding "[...] the most common Indus sign of all" in the context of the script of the Indus Valley civilization; cf. MELKA, T. S., SCHOCH, R. M. The Quest for Information Retrieval: An Inscribed Relic from Ancient Rapa Nui (Easter Island), Part I. 